Atmos. Chem. Phys. Discuss., 10, 9391-9430, 2010 www.atmos-chem-phys-discuss.net/10/9391/2010/ (C) Author(s) 2010. This work is distributed under the Creative Commons Attribution 3.0 License.

This discussion paper is/has been under review for the journal Atmospheric Chemistry and Physics (ACP). Please refer to the corresponding final paper in ACP if available.

\title{
Composition and sources of particulate matter in an industrialised Alpine valley
}

N. Perron ${ }^{1}$, J. Sandradewi ${ }^{1}$, M. R. Alfarra ${ }^{1,{ }^{\star}}$, P. Lienemann ${ }^{2,{ }^{\star \star}}$, R. Gehrig ${ }^{2}$, A. Kasper-Giebl ${ }^{3}$, V. A. Lanz ${ }^{1}$, S. Szidat ${ }^{4,5}$, M. Ruff ${ }^{4}$, S. Fahrni ${ }^{4,5}$, L. Wacker ${ }^{6}$, U. Baltensperger ${ }^{1}$, and A. S. H. Prévôt ${ }^{1}$

${ }^{1}$ Laboratory of Atmospheric Chemistry, Paul Scherrer Institut, 5232 Villigen PSI, Switzerland ${ }^{2}$ Swiss Federal Laboratories for Materials Testing and Research (Empa), 8600 Duebendorf, Switzerland

${ }^{3}$ Institute of Chemical Technologies and Analytics, Vienna University of Technology, Getreidemarkt 9/164-UPA, 1060 Vienna, Austria

${ }^{4}$ Department of Chemistry and Biochemistry, University of Bern, Freiestrasse 3, 3012 Bern, Switzerland

${ }^{5}$ Oeschger Centre for Climate Change Research, University of Bern, 3012 Bern, Switzerland ${ }^{6}$ Institute for Particle Physics, ETH Hönggerberg, 8093 Zürich, Switzerland
ACPD

10, 9391-9430, 2010

Composition and sources of particulate matter

N. Perron et al.

Title Page

Abstract

Introduction

Conclusions

References

Tables

Figures

14

I

4

Back

Close

Full Screen / Esc

Printer-friendly Version

Interactive Discussion 
${ }^{*}$ now at: National Centre for Atmospheric Science (NCAS), School of Earth, Atmospheric and Environmental Sciences, University of Manchester, Manchester, M60 1QD, UK

${ }^{* *}$ now at: Zürcher Hochschule für Angewandte Wissenschaften, Life Sciences und Facility Management, Einsiedlerstr. 31, 8820 Wädenswil, Switzerland

Received: 1 April 2010 - Accepted: 6 April 2010 - Published: 14 April 2010

Correspondence to: A. S. H. Prévôt (andre.prevot@psi.ch)

Published by Copernicus Publications on behalf of the European Geosciences Union.

\section{ACPD}

10, 9391-9430, 2010

Composition and sources of particulate matter

N. Perron et al.

Title Page

Abstract

Introduction

Conclusions

References

Tables

Figures

14

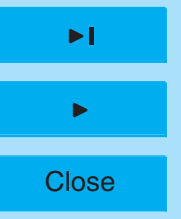

Back

Full Screen / Esc

Printer-friendly Version

Interactive Discussion 


\section{Abstract}

A three-week long field campaign was carried out under autumnal meteorological conditions at four valley floor sites in the industrialised Swiss Rhone Valley. For one week of stable meteorological conditions, particulate matter with an aerodynamic diameter below $10 \mu \mathrm{m}\left(\mathrm{PM}_{10}\right)$ was analysed from daily filters using ion chromatography, X-ray fluorescence, anhydrosugars and radiocarbon analysis of the organic and elemental matter (OM and $\mathrm{EM}$, respectively). Furthermore, $\mathrm{PM}_{1}$ composition along the whole campaign was monitored in Massongex (a site near industries) by a seven-wavelength aethalometer and a quadrupole aerosol mass spectrometer (Q-AMS). At all sites, $\mathrm{PM}_{10}$ secondary inorganics and non-fossil EM and OM exhibited relatively stable concentrations over the selected days. On the contrary, $\mathrm{PM}_{10}$ fossil carbonaceous fractions, mineral dust components and several trace elements showed a significant decrease on Sunday, compared to the analysed working days. Their concentrations were also highly correlated. This evidenced the role of exhaust and resuspension emissions by heavy-duty vehicle traffic to the $\mathrm{PM}_{10}$ concentrations along the valley.

In Massongex, organic matter and black carbon (BC) were the main contributors to $\mathrm{PM}_{1}$ over the campaign (accounting for $45 \%$ and $18 \%$ of $\mathrm{PM}_{1}$, respectively). An optical discrimination of $\mathrm{BC}$ highlighted the prevalence of fossil over wood-burning sources. Three types of $\mathrm{PM}_{1}$ organics could be identified by factor analysis: primary wood-burning organic aerosol (P-WBOA) dominated the $\mathrm{PM}_{1}$ carbonaceous fraction, followed by oxygenated organics (OOA) mostly representing secondary organics, and by traffic or possibly industry-related hydrocarbon-like organics (HOA) as the smallest carbonaceous contribution.

Furthermore, unusually high contributions of fine chloride were detected at all sites.
They were attributed to ammonium chloride $\left(\mathrm{NH}_{4} \mathrm{Cl}\right)$ in Massongex and represented the only significant component exclusively attributable to industrial emissions.
Composition and sources of particulate matter

N. Perron et al.

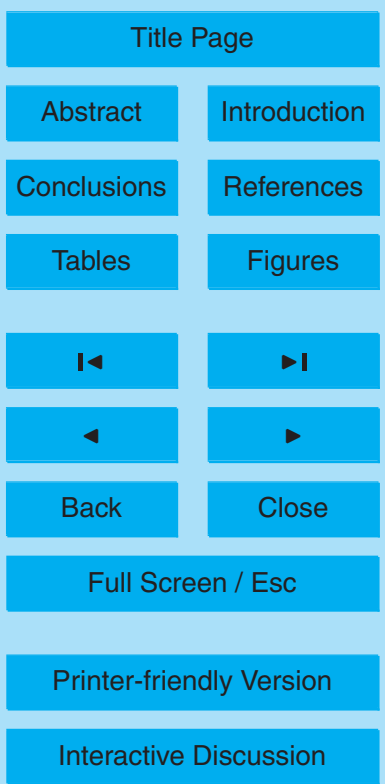




\section{Introduction}

Particulate matter with an aerodynamic diameter below $10 \mu \mathrm{m}\left(\mathrm{PM}_{10}\right)$ corresponds to the size range of particles that can readily penetrate and deposit in the respiratory system, thus being potentially detrimental to human health. Indeed, several studies 5 have evidenced a link between $\mathrm{PM}_{10}$ increase and enhanced adverse health effects such as hospitalisation for myocardial infarction (e.g. Miller et al., 2007) or premature mortality (Mokdad et al., 2004). High $\mathrm{PM}_{10}$ concentrations can also enhance the sensitivity for other pathologies, foster chronic respiratory diseases and contribute to hinder the development of new-born children's pulmonary capacity (Latzin et al., 2009). In Switzerland, about 3700 premature deaths per year are imputed to $\mathrm{PM}_{10}$, which corresponds to a loss of more than 40000 years of life (Röösli et al., 2005), or to 6 months of the population life expectancy. Guidelines issued by the WHO recommend maximum $\mathrm{PM}_{10}$ concentrations of $50 \mathrm{\mu g} \mathrm{m}^{-3}$ as daily average and $20 \mu \mathrm{g} \mathrm{m}^{-3}$ as yearly average (WHO, 2006). These thresholds have also been adopted by the Swiss legislation since 15 1998, but are still regularly exceeded in winter time (Barmpadimos et al., 2010). This is particularly true in Alpine valleys, where the topography, the local meteorology and the presence of significant emitters such as traffic and residential wood combustion create potential conditions for intense particulate pollution episodes. In the case of the industrialised Swiss Rhone valley, this is particularly critical, as $60 \%$ of the population of the Swiss canton of Valais are exposed to this excessive pollution (Résival, 2006). Therefore, needs for targeted abatement policies are important and require a better knowledge of PM composition and sources. Such source apportionment studies have already been performed in Alpine valleys and have mainly focused on the contribution of the carbonaceous aerosol to particulate pollution, investigating its sources and EC) (Aymoz et al., 2007), their respective radiocarbon $\left({ }^{14} \mathrm{C}\right.$ ) compositions (Szidat et al., 2007), sometimes combined with on-line aerosol mass spectrometer (AMS) measurements (Alfarra et al., 2007). Aerosol light absorption at different wavelengths

Composition and sources of particulate matter

N. Perron et al.

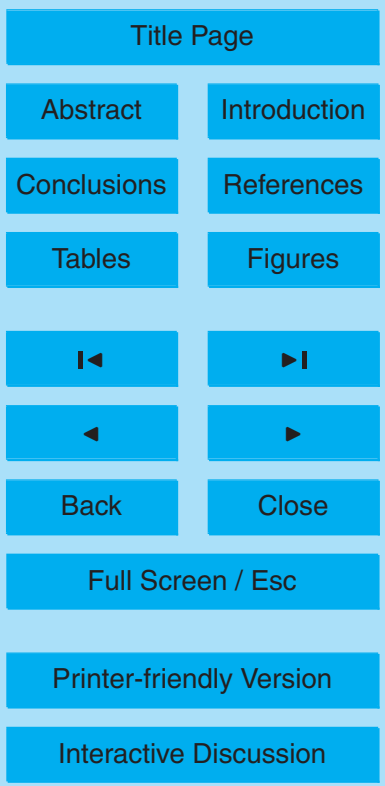


(Sandradewi et al., 2008a) was also exploited and compared to results of chemical mass balance and factorial analysis of AMS organics (Favez et al., 2010). In this study, the combination of different analytical techniques such as ion chromatography, X-ray fluorescence, liquid chromatography for the determination of anhydrosugars and ra5 diocarbon analyses of $\mathrm{OC}$ and EC enabled a detailed characterisation of $\mathrm{PM}_{10}$ at four different floor sites along the Swiss Rhone valley. In addition, AMS and aethalometer $\mathrm{PM}_{1}$ measurements at one site allowed an enhanced characterisation of the fine fraction of the $\mathrm{PM}_{10}$.

\section{Observation area and meteorology}

\subsection{Measurement area}

The campaign was conducted from 22 November to 17 December 2006 in the Swiss Rhone valley. This 1.8 to $3.6-\mathrm{km}$ broad, U-shaped valley stretches over about $80 \mathrm{~km}$ and broadens downwards, opening to the Rhone plain between Massongex and Lake Geneva (Fig. 1). Due to its particular topography, this deep valley surrounded by high mountain chains constitutes a specific ventilation and meteorological system, similar to the Mesolcina valley (Prévôt et al., 2000). However, the Rhone valley is more secluded in the Central Alps and the rather frequent foehn conditions lead to a warmer and dryer climate than in the neighbouring regions.

The valley floor hosts most of the population of the Swiss Rhone valley and exhibits also the highest $\mathrm{PM}_{10}$ concentrations (Résival, 2006). Therefore, four valley floor stations of the air quality monitoring network of Valais Canton (Résival, 2006) were selected as $\mathrm{PM}_{10}$ sampling locations (Table 1). Among them, Massongex is a rural site located a few kilometres away from chemical and petrochemical industries and from the motorway. The station of Saxon is a rural site downwind from industries, between the 25 motorway located $400 \mathrm{~m}$ away in the northwest and the cantonal road in the southeast. The station in Sion, the largest city in the valley with 28000 inhabitants, is installed on

Composition and sources of particulate matter

N. Perron et al.

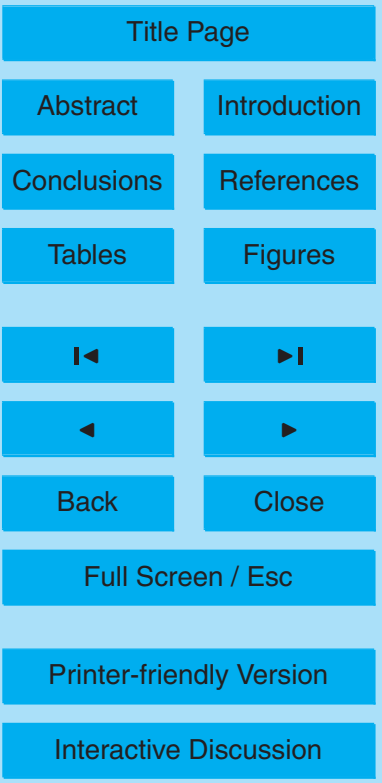

Interactive Discussion 
a parking lot in the town centre, close to the big roadways of the city. Last, Brigerbad is a rural site located at a higher altitude and surrounded by industries situated a few kilometres away in the west and the east.

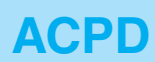

\subsection{Meteorological conditions during the campaign}

5 Average temperatures during the campaign ranged from $2.1^{\circ} \mathrm{C}$ in Brigerbad to $6.4^{\circ} \mathrm{C}$ in Massongex, where temperatures below $0^{\circ} \mathrm{C}$ were seldom observed.

At all stations, the campaign divides into two kinds of meteorological periods (Fig. 2): the first and third complete weeks were characterised by stable meteorological conditions including rather low temperatures, higher $\mathrm{PM}_{10}$ concentrations as well as weak winds (typically less than $2 \mathrm{~m} \mathrm{~s}^{-1}$ wind speed at $2 \mathrm{~m}$ above ground level) showing no consistent direction. The second week experienced higher wind speeds and temperatures, as well as lower $\mathrm{PM}_{10}$ concentrations.

Due to the stable meteorological conditions characterising the week of 27 November to 3 December 2006 at all sites, the high $\mathrm{PM}_{10}$ concentrations can be regarded as 15 resulting mainly from locally produced aerosols. Consequently, five days of this week (further related to as "week 1") were selected for $\mathrm{PM}_{10}$ analyses: Tuesday, Wednesday and Friday to Sunday (28 and 29 December, 1-3 December 2006). Additional filters, corresponding to 26 and 27 November and 5 December 2006 were analysed for Massongex.

\section{Instrumentation}

\subsection{Sampling methodology}

$\mathrm{PM}_{10}$ aerosols were collected at the four stations on a $24 \mathrm{~h}$-basis (from midnight to midnight) on pre-heated $\left(8 \mathrm{~h}\right.$ at $900^{\circ} \mathrm{C}$ ) quartz-fibre filters (Pall 2500 QAT-UP; Pallflex Products Co., USA, $150 \mathrm{~mm}$ diameter) with high-volume samplers (DHA-80, Digitel

Composition and sources of particulate matter

N. Perron et al.

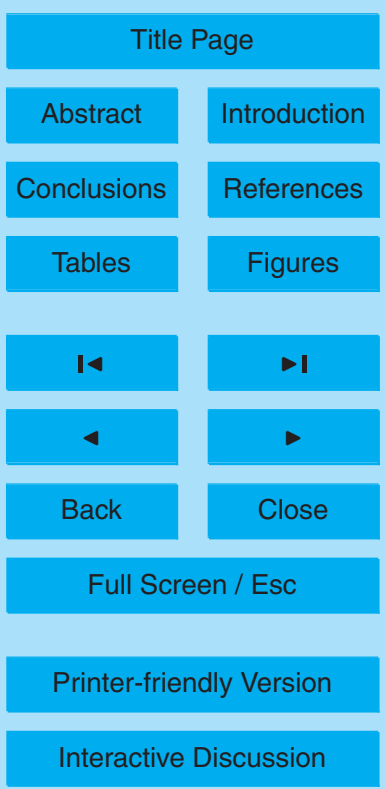

Interactive Discussion 
Elekronik AG, Hegnau, Switzerland - about $30 \mathrm{~m}^{3} / \mathrm{h}$ flow rate). After sampling, the filters were wrapped in aluminium foils, packed into air-tight polyethylene bags and stored at $-20^{\circ} \mathrm{C}$ for later off-line analyses (Table 2).

To characterise the $\mathrm{PM}_{1}$ fraction, additional instruments were set up in Massongex 5 (Table 2): a Rupprecht and Patashnick TEOM Series 1400a real-time monitor heated at $30^{\circ} \mathrm{C}$, an Aerodyne quadrupole aerosol mass spectrometer (Q-AMS, Canagaratna et al., 2007) and a seven-wavelength aethalometer (AE31, Magee Scientific). They were operated in a temperature-controlled measurement container located by the monitoring station on the fringe of the village.

Additional meteorological parameters such as ambient temperature, ambient pressure, ambient relative humidity, wind speed and directions, as well as air quality data including $\mathrm{CO}, \mathrm{NO}, \mathrm{NO}_{2}, \mathrm{O}_{3}, \mathrm{SO}_{2}$ and $\mathrm{PM}_{10}$ concentrations were also continuously monitored and recorded by the Environmental Protection Agency of the Canton Valais at the four measuring sites. A list of the corresponding analytical methods can be found in their annual report (Résival, 2006).

\section{2 $\mathrm{PM}_{10}$ analyses}

\subsection{1 $\mathrm{PM}_{10}$ concentrations}

At all stations, the $\mathrm{PM}_{10}$ total mass was measured using a beta-meter (Thermo Electron FHT 62-IR). This instrument contains a small ${ }^{14} \mathrm{C}$ beta source coupled to a sensitive detector that counts the emitted beta particles. The beta ray transmission across a filter tape is measured before and after particulate matter collection on this filter section and the difference converted to a particulate concentration by calibration with $\mathrm{PM}_{10}$ weighted filters.

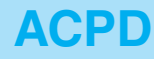

10, 9391-9430, 2010

Composition and sources of particulate matter

N. Perron et al.

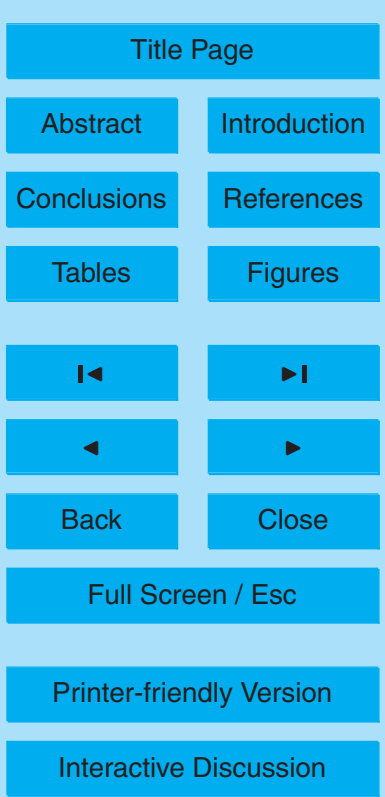




\subsubsection{Radiocarbon analyses $\left({ }^{14} \mathrm{C}\right)$ of organic and elemental matter}

Carbonaceous species are traditionally divided into two fractions: organic carbon $(\mathrm{OC})$ and elemental carbon $(\mathrm{EC})$ or black carbon $(\mathrm{BC})$. The two different names given to the latter fraction depends on whether its analysis relies on its thermal refractivity $(E C)$ or on its strong light absorption properties (BC), thus leading to possible discrepancies.

The radiocarbon signatures of $\mathrm{OC}$ and $\mathrm{EC}$ for the selected $\mathrm{PM}_{10}$ filters were investigated, according to the method described in Szidat et al. (2006). For each sample $\mathrm{OC}$ was removed from one filter punch by oxidation in pure $\mathrm{O}_{2}$ at $340^{\circ} \mathrm{C}$, and EC was combusted at $650^{\circ} \mathrm{C}$ from two additional filter punches after removal of the OC by water extraction and oxidation in air at $375^{\circ} \mathrm{C}$ during $4 \mathrm{~h}$ (Szidat et al., 2004). For each type of sample, the resulting $\mathrm{CO}_{2}$ was trapped cryogenically and stored in sealed glass ampoules for later off-line analysis, using the gas ion source of the accelerator mass spectrometer MICADAS (Ruff et al., 2007). Average recoveries for OC and EC amounted to $80 \%$ and $60 \%$, respectively, of the masses measured by the OC/EC anal15 yser. The recovered material was assumed to be representative of the whole fraction and therefore to present a similar radiocarbon signature. Results of the ${ }^{14} \mathrm{C}$ measurements were expressed in fractions of modern carbon (fM), which corresponds to the ${ }^{14} \mathrm{C} /{ }^{12} \mathrm{C}$ ratios of the samples normalised to that of the reference year 1950 (Stuiver and Polach, 1977). The carbonaceous aerosol was considered as stemming either following $\mathrm{fM}$ values: $\mathrm{fM}_{\mathrm{f}}=0, \mathrm{fM}_{\mathrm{bio}}=1.055$ and $\mathrm{fM}_{\mathrm{wb}}=1.16 \pm 0.05$ (Szidat et al., 2009).

Using the measured fM's, the EC and OC concentrations deduced from EC/OC offline analyses with a Sunset EC/OC analyser (Bae et al., 2004) and a modified NIOSH thermal program (Birch and Cary, 1996) were apportioned to their respective fossil and

non-fossil parts $\mathrm{EC}_{\mathrm{f}}, \mathrm{EC}_{\mathrm{wb}}, \mathrm{OC}_{\mathrm{f}}$ and $\mathrm{OC}_{\mathrm{nf}}$. The latter was regarded as a $50 \% / 50 \%$ mix of biogenic and biomass-burning sources, furthering the absence of more detailed information. If all non-fossil carbon were assumed to stem from wood burning, this would lower down the determined $\mathrm{OC}_{\mathrm{nf}}$ concentrations by $5 \%$.
10, 9391-9430, 2010

\section{Composition and sources of particulate matter}

N. Perron et al.

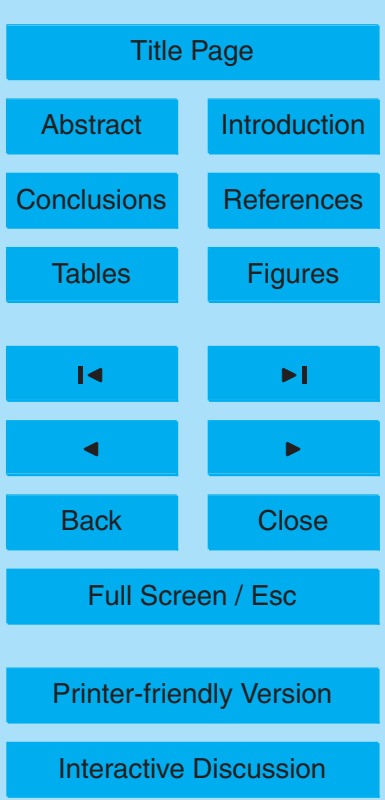

Interactive Discussion 
The above mentioned carbon fractions were then converted to their respective total aerosol mass by using conversion ratios. $(\mathrm{OM} / \mathrm{OC})_{\mathrm{nf}}=1.7$ and $(\mathrm{OM} / \mathrm{OC})_{\mathrm{f}}=1.5$ were estimated from Aiken et al. (2008), considering that non-fossil OM consists of a mix of primary wood-burning emission and secondary non-fossil organic aerosol, but less 5 aged than in Mexico, whereas fossil OM contains primary and secondary fossil organics. Furthermore, $(E M / E C)=1.1$ was used for both fossil and non-fossil sources.

\subsubsection{Anhydrosugars (levoglucosan, mannosan)}

Biomass burning induces high emissions of anhydrosugars resulting from the thermal degradation of structural biomass polysaccharides. Resulting from the pyrolysis of cellulose, levoglucosan is the most abundantly emitted anhydrosugar and has been widely used as a tracer of biomass burning (Simoneit et al, 1999; Fraser et al., 2000). Its emissions are followed in importance by those of mannosan (Caseiro et al., 2009; Schmidl et al., 2008), produced by the pyrolysis of hemicellulose.

In this study, anhydrosugar analysis was performed by sonicating in Milli-Q water 21$\mathrm{mm}$ diameter punches of the selected $\mathrm{PM}_{10}$ HiVol filters and by analysing the aqueous extract with a high-pressure liquid chromatography (HPLC) column for carbohydrate separation (Puxbaum et al., 2007; Caseiro et al., 2007).

\subsubsection{Major ions and trace metals}

To analyse major ions $\left(\mathrm{Cl}^{-}, \mathrm{NO}_{3}^{-}, \mathrm{SO}_{4}^{2-}, \mathrm{Na}^{+}, \mathrm{NH}_{4}^{+}, \mathrm{K}^{+}, \mathrm{Mg}^{2+}\right.$ and $\left.\mathrm{Ca}^{2+}\right), 25-\mathrm{mm}$ diameter punches of the selected $\mathrm{PM}_{10}$ filter were placed in $50 \mathrm{~mL}$ milli-Q water, agitated and then left overnight (about $12 \mathrm{~h}$ ) before being agitated once again. The resulting extract was then filtered and analysed with ion chromatography (IC).

The selected filters also provided $40 \mathrm{~mm}$-diameter punches used to analyse the following elements: $\mathrm{Pb}, \mathrm{Zn}, \mathrm{Cu}, \mathrm{Ni}, \mathrm{Fe}, \mathrm{Mn}, \mathrm{Cr}, \mathrm{Ca}, \mathrm{K}, \mathrm{S}, \mathrm{P}, \mathrm{Al}, \mathrm{Mg}$, and $\mathrm{Na}$ by wave25 length dispersive X-ray fluorescence spectrometry (WD-XRF) (Gehrig et al., 2007). The XRF technique measures the total amount of each element, whereas IC deter-

Composition and sources of particulate matter

N. Perron et al.

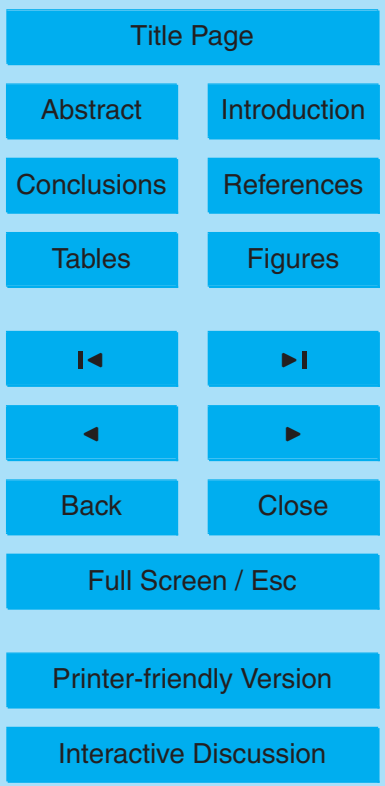


mines water-soluble species. For most of the elements measured by both analytical techniques, such as $\mathrm{S}$ (measured as sulphate by IC), $\mathrm{K}, \mathrm{Na}$, and $\mathrm{Ca}$, high correlations with slopes between 0.78 and 1.30 were found between both methods (Fig. S1 in the supplementary material, see http://www.atmos-chem-phys-discuss.net/10/9391/2010/

5 acpd-10-9391-2010-supplement.pdf), indicating a reasonable agreement between the two techniques, and that these species were mainly in a water-soluble form. On the contrary, the Mg concentrations for XRF were twice as high as for IC and the correlation was lower, due probably to a lower water-soluble fraction. Further evaluation of the total $\mathrm{PM}_{10}$ composition was performed by using XRF-deduced concentrations.

10 Due to the use of quartz-fibre filters as a collection medium, Si could not be detected in the $\mathrm{SiO}_{2}$ matrix, therefore a ratio $\mathrm{Si} / \mathrm{Al}$ of 3.41 was applied to estimate the Si concentrations from those of Al, as already done by Hueglin et al. (2005) for other sites in Switzerland.

Elements $\mathrm{Al}, \mathrm{Mg}, \mathrm{Ca}, \mathrm{Fe}, \mathrm{Si}$ and $\mathrm{K}$ were assumed to stem mainly from mineral dust, 15 the mass concentration of which was estimated by considering these metals as oxides (Chow et al., 2002; Hueglin et al., 2005; Marenco et al., 2006). Therefore, the metal mass concentrations were scaled to those of the associated oxides using the equation:

$[$ Mineral dust $]=1.89[\mathrm{Al}]_{\mathrm{tot}}+1.66[\mathrm{Mg}]_{\mathrm{tot}}+1.40[\mathrm{Ca}]_{\mathrm{tot}}+1.43[\mathrm{Fe}]_{\mathrm{tot}}+2.14[\mathrm{Si}]_{\mathrm{tot}}+1.21[\mathrm{~K}]_{\mathrm{tot}}$.

\section{3 $\mathrm{PM}_{1}$ analyses}

\subsubsection{Aethalometer-based source apportionment of BC}

The multi-wavelength aethalometer equipped with a $\mathrm{PM}_{1}$ inlet delivered $\mathrm{PM}_{1}-\mathrm{BC}$ concentrations measured at $880 \mathrm{~nm}$ as well as attenuation coefficient $b_{\text {ATN }}$ of the sampled aerosol at $370,470,550,520,590,660,880$ and $950 \mathrm{~nm}$. Since the raw $b_{\text {ATN }}$ values correspond to filter-deposited particles, they are biased by multiple scattering of the 25 light within the filter fibres and by the "shadowing" effect occurring at high filter loads. These artefacts were corrected according to the procedure described by Weingartner

Composition and sources of particulate matter

N. Perron et al.

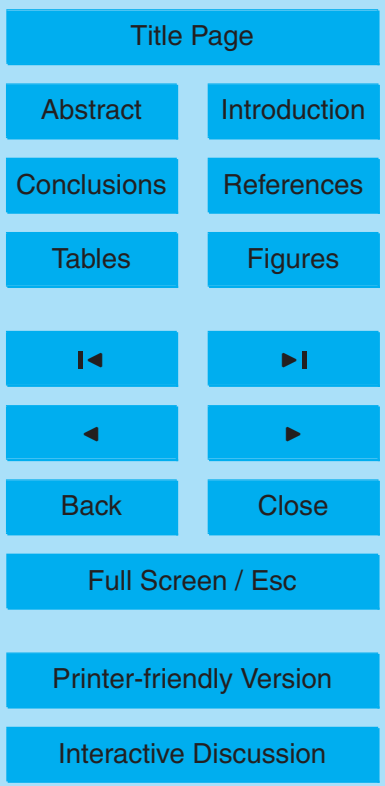

Interactive Discussion 
et al. (2003) to yield the absorption coefficients, $b_{\mathrm{abs}}$, corresponding to airborne particles.

In winter, the ambient fine light-absorbing aerosol fraction present in Switzerland (where no combustion of coal is performed) can be regarded as resulting from two 5 main contributions: the brown-carbon-rich (Andreae and Gelencsér, 2006; Lukács et al., 2007; Alexander et al., 2008) aerosol emitted by biomass burning (Reid et al., 2005) on the one hand and the fossil fuel combustion aerosol (including mostly traffic, but also industry and heating oil) on the other hand. Mineral dust, which can also absorb light (Moosmüller et al., 2009), was neglected because it is mostly absent from the sub10 micron mode and likely negligible in absolute light absorption coefficient concentrations values.

Relying on the work by Sandradewi et al. (2008b), we calculated the absorption coefficients for both sources at 470 and $950 \mathrm{~nm}$, using the following Ångström absorption exponents: $\alpha_{\mathrm{wb}}=1.86$, empirically determined by Sandradewi et al. (2008b) for 15 wood burning during winter campaigns in a Swiss Alpine valley, and $\alpha_{\mathrm{t}}=1$ for the traffic source.

$\mathrm{BC}$ measurements were performed at $880 \mathrm{~nm}$, where it is considered to be the only light absorber, by converting the retrieved $b_{\mathrm{abs}}(950)_{\mathrm{t}}$ to $b_{\mathrm{abs}}(880)_{\mathrm{t}}$ with the following equation:

$20 \frac{b_{\mathrm{abs}}(880)_{\mathrm{t}}}{b_{\mathrm{abs}}(950)_{\mathrm{t}}}=\left(\frac{880}{950}\right)^{-\alpha_{\mathrm{t}}}$

This allowed to calculate the contribution of both sources to BC by considering:

$\mathrm{BC}_{\mathrm{t}}=\frac{b_{\mathrm{abs}}(880)_{\mathrm{t}}}{b_{\mathrm{abs}}(880)} * \mathrm{BC}$

and:

$B C_{w b}=B C-B C_{t}$

Composition and sources of particulate matter

N. Perron et al.

Title Page

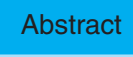

Introduction

Conclusions

Tables

References

Figures

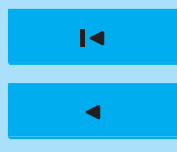

Back

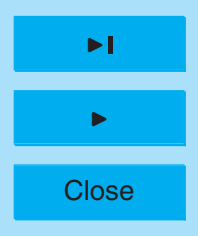

Full Screen / Esc

Printer-friendly Version

Interactive Discussion

9401 


\subsubsection{AMS and aethalometer source apportionment of $\mathrm{PM}_{1}$ organics}

The non-refractory fraction of the sub-micrometer aerosol includes $\mathrm{OM}, \mathrm{NO}_{3}^{-}, \mathrm{SO}_{4}^{2-}$, $\mathrm{NH}_{4}^{+}$and $\mathrm{Cl}^{-}$, which were analysed with on-line aerosol mass spectrometry (Q-AMS). Because part of the mass of the sampled aerosol bounces off the AMS heater and is therefore not measured (Alfarra et al., 2004), a collection efficiency (CE) is applied to the AMS measurements to yield the absolute concentrations. In our case, the CE was determined by comparing the sum of the AMS and aethalometer measurements (OM $+\mathrm{NO}_{3}^{-}+\mathrm{SO}_{4}^{2-}+\mathrm{NH}_{4}^{+}+\mathrm{Cl}^{-}+\mathrm{BC}$ ) with the total $\mathrm{PM}_{1}$ concentrations provided by the TEOM. A good agreement between the two datasets was found when applying a CE of 0.5 (see Sect. 4.2.1).

The different sources or components of AMS organics were investigated by applying factor analytical modelling - more specifically, positive matrix factorisation (Paatero and Tapper, 1994) and the multilinear engine (Paatero, 1999) - to the organic aerosol mass spectra (Lanz et al., 2007, 2008).

\section{Results and discussion}

\section{1 $\mathrm{PM}_{10}$ composition}

\subsubsection{Total mass}

From 27 November to 3 December 2006, Brigerbad exhibited the highest average $\mathrm{PM}_{10}$ concentrations $\left(\sim 60 \mu \mathrm{g} \mathrm{m}^{-3}\right)$ whereas the other three stations exhibited equivalent amounts $\left(\sim 40 \mathrm{\mu g} \mathrm{m}^{-3}\right)$. The $\mathrm{PM}_{10}$ compositions for the corresponding three working days (Tuesday, Wednesday and Friday) and Sunday are presented in Fig. 3. $\mathrm{PM}_{10}$ on Saturday exhibited an intermediate composition between the working days and Sunday and is not shown here. Compositions of $\mathrm{PM}_{10}$ at all stations showed rather similar patterns. In all cases, the carbonaceous aerosol and especially the non-fossil OM were

Composition and sources of particulate matter

N. Perron et al.

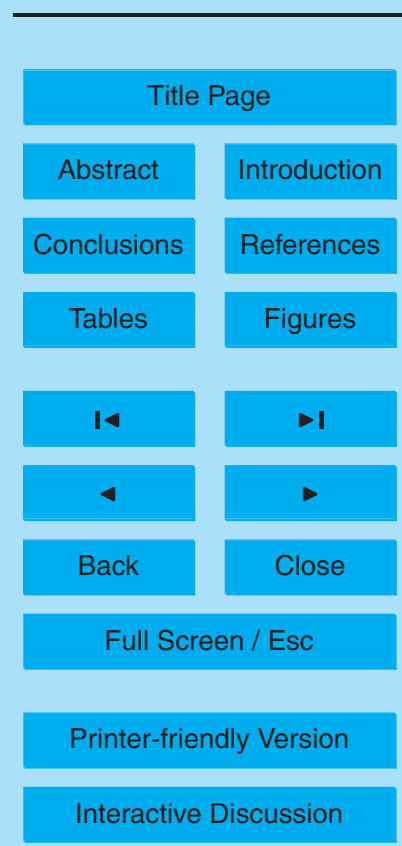


dominant, the latter representing 19 to $31 \%$ of the total $\mathrm{PM}_{10}$ on the working days and 35 to $42 \%$ on the Sunday. As expected, the city centre site of Sion exhibited the highest fossil contributions to OM and EM, and was followed by Brigerbad, whereas Saxon and Massongex showed lower fossil contributions to OM and EM. A significant part of the $5 \mathrm{PM}_{10}$ mass was also constituted by the secondary inorganics, which represented 11 to $20 \%$ of the $\mathrm{PM}_{10}$ on the working days and 27 to $37 \%$ on Sunday. Additionally, chloride contributed also noticeably to $\mathrm{PM}_{10}$ (up to $12 \%$ ).

At all sites, a significant fraction ranging from 11 to $29 \%$ remained unaccounted on the working days, and was lower on Sunday (Table 3). Several studies (e.g. Putaud 10 et al., 2004; Hueglin et al., 2005) stated that the remaining unaccounted mass fraction typically represents $30 \%$ of the total $\mathrm{PM}_{10}$, when considering an $\mathrm{OM} / \mathrm{OC}$ of 1.4 . This remainder is thought to result from aerosol-bound water and from random and possibly systematic errors, including too low OM/OC ratios.

\subsubsection{Traffic-related emissions}

15 The lower concentrations measured on the Sunday concern notably $\mathrm{OM}_{\mathrm{f}}$ and $\mathrm{EM}_{\mathrm{f}}$, which were approximately cut by half between the considered working days and Sunday at all stations, whereas no such trend was observed for the non-fossil OM and EM (Table 3).

The stable meteorological conditions recorded during week 1 as well as the con20 stancy of the biomass-burning EM concentrations at all sites suggests that meteorology played a negligible role for the $\mathrm{PM}_{10}$ fluctuations during this period. Therefore, variations in $\mathrm{PM}_{10}$ observed on the different days result mainly from the variations of the intensities in emissions or secondary formation processes.

In this case, the reduction of the carbonaceous PM by up to $26 \%$ on Sunday 3 25 December 2006 compared to the working days can be attributed to a reduction of the fossil source emissions. The ban on dominical truck circulation imposed by the Swiss legislation is more likely to cause such a drop than the variations of emissions from oil refineries, which keep some activity also on Sundays. This indicates a significant

Composition and sources of particulate matter

N. Perron et al.

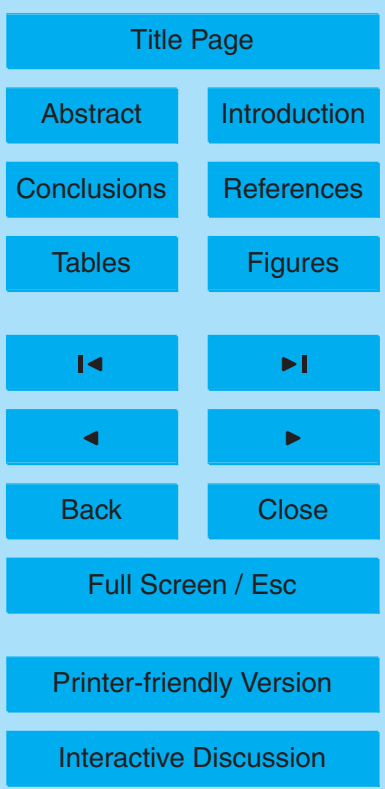


influence of traffic on $\mathrm{PM}_{10}$ emissions all along the valley during working days and highlights the importance of heavy-duty traffic in the fossil emissions.

The elements $\mathrm{Cu}, \mathrm{Zn}$ and $\mathrm{Mn}$ stem to some extent from brake abrasion, tyre wear (Thorpe and Harrison, 2008 and references therein) and fossil fuel combustion (Pacyna 5 and Pacyna, 2001), respectively. This explains why they are highly correlated with $\mathrm{EM}_{\mathrm{f}}$ (Table 4). High correlations with $\mathrm{EM}_{\mathrm{f}}$ were also observed for the crustal elements (such as $\mathrm{Ca}, \mathrm{Mg}, \mathrm{Fe}$, and $\mathrm{Al}$ ) associated with mineral dust, and for $\mathrm{Na}$, possibly coming from the salt sprinkled on the roads for deicing or from natural sources (Fig. 4). Simirlarly to $\mathrm{EM}_{\mathrm{f}}$, all these species showed also a dominical decrease in concentrations, compared 10 to the working days.

The interpretation that working day traffic is the main reason for the enhanced concentrations of $\mathrm{Ca}, \mathrm{Mg}, \mathrm{Fe}, \mathrm{Al}$, and $\mathrm{Na}$ is also supported by the low correlations between these elements and $\mathrm{EM}_{\mathrm{wb}}$ on the one hand, and between $\mathrm{EM}_{\mathrm{f}}$ and the mainly secondary species $\mathrm{NH}_{4}^{+}, \mathrm{NO}_{3}^{-}$and $\mathrm{SO}_{4}^{2-}$ on the other hand. This is consistent with the 15 findings of Gehrig et al. (2004) that road traffic represents a significant source of abrasion and resuspension-induced $\mathrm{PM}_{10}$. Moreover, Bukowiecki et al. (2010) showed that resuspension due to trucks is much more important than for gasoline cars, providing an explanation for this pattern. We expect the traffic dependence in this Alpine valley to be especially important during low-wind conditions like in week 1 , because higher wind speed could cause considerable resuspension of crustal particles in the air, masking the effect due to traffic.

\subsubsection{Wood-burning emissions}

At all stations, non-fossil OC concentrations remained relatively constant over the whole week (Table 3). To assess the primary wood-burning contribution $\mathrm{OC}_{\mathrm{nf}}$, the anhydrosugar (levoglucosan and mannosan) concentrations were compared to $\mathrm{OC}_{\mathrm{nf}}$ concentrations (Fig. 5). Slope values of the scatterplots amount to 3.5 for levoglucosan and 29.1 for mannosan (Fig. 5). The slope for the former plot is lower than most OC/levoglucosan emission ratios compiled by Puxbaum et al. (2007), who recommend

Composition and sources of particulate matter

N. Perron et al.

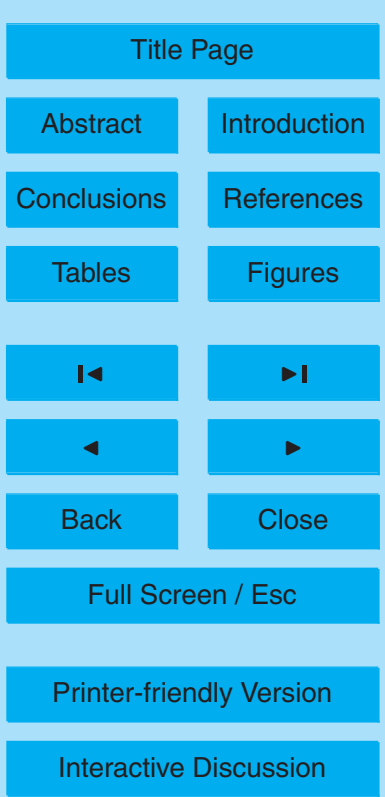


a value of 7.35 for the Alpine region. The lower value found in our case suggests other origins of non-fossil OC than primary wood-burning. It could be partly due to the fact that wood-burning exhaust can produce significant additional secondary organic mass within a few hours of aging (Grieshop et al., 2009). However, the intercepts of $5 \sim 3.4 \mu \mathrm{g} \mathrm{cm}^{3} \mathrm{OC}_{\mathrm{nf}}$ found in Fig. 5 in the absence of anhydrosugars supports the contribution of other $\mathrm{OC}_{\mathrm{nf}}$ sources, such as secondary production from biogenic gaseous precursors, but also resuspension of primary biological particles. In our case, applying a OC/levoglucosan ratio of 7.35 led to wood-burning OC concentrations exceeding those of $\mathrm{OC}_{\mathrm{nf}}$. Considering a lower range value of 6 as proposed by Gelencsér et 10 al. (2007) was more realistic and yielded wood-burning contributions to OC of $63-100 \%$ for Massongex, $80-100 \%$ for Saxon, $39-50 \%$ for Sion and $70-75 \%$ for Brigerbad.

\subsubsection{Other sources and summary for $\mathrm{PM}_{10}$ contributions}

As pointed out earlier, industry-related $\mathrm{Zn}$ was observed in Saxon. Particulate $\mathrm{Cl}^{-}$concentrations exceeding by far those of $\mathrm{Na}^{+}$and therefore originating from other sources 15 of chloride than $\mathrm{NaCl}$ suggested additional emissions of industrial origin. In Fig. 6, the $\mathrm{PM}_{10}$ source apportionment averaged for the four stations is presented for the working days and the Sunday. It highlights the strong reduction of traffic-related aerosol sources such as dust resuspension and carbonaceous fossil emissions on the one hand, and the stability of the concentrations of non-fossil carbonaceous aerosol, which includes 20 wood burning. Although this picture has been drawn using only one week of data, it has been found to be consistent at the four sites along the Swiss Rhone Valley.

\section{2 $\mathrm{PM}_{1}$ chemical composition}

\subsubsection{Validation of the AMS collection efficiency (CE)}

The right-hand panel of Fig. 7 shows a scatterplot of the $\mathrm{PM}_{1}$ total mass concentration measured by the TEOM and from the sum of BC and AMS total mass concentrations

Composition and sources of particulate matter

N. Perron et al.

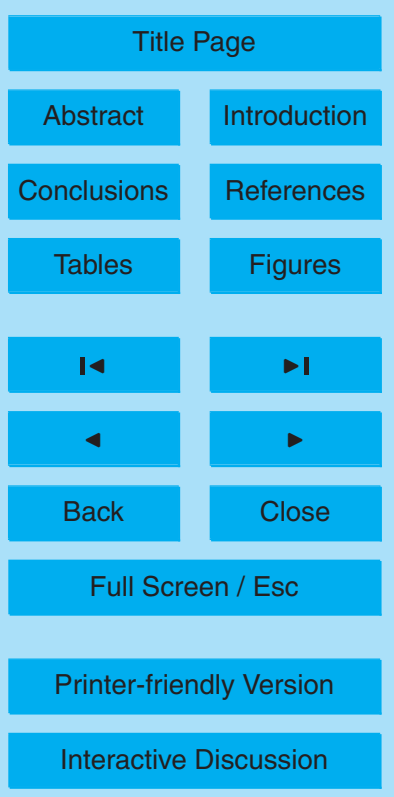

Interactive Discussion 
using a CE value of 0.5. A good agreement between both methods is noted, thus validating the choice of $\mathrm{CE}=0.5$. The lower agreement observed for the days with lowest $\mathrm{PM}_{1}$ loadings stems probably from the lack of accuracy and precision of the TEOM at low concentrations. Since $\mathrm{NH}_{4}^{+}$belongs exclusively to $\mathrm{PM}_{1}$, the consistency 5 between $\mathrm{NH}_{4}^{+}$concentrations from $\mathrm{PM}_{10}$ filters and from $24 \mathrm{~h}$-averaged AMS values (slope $=0.9, r^{2}=0.97,9$ samples) provided an additional support to the choice of the CE value.

\subsection{2 $\mathrm{PM}_{1}$ general composition during the week 1}

The $\mathrm{PM}_{1}$ average mass amounted to $11.4 \mu \mathrm{gm}^{-3}$ over the whole campaign and to $10 \quad 16.9 \mathrm{\mu g} \mathrm{m}^{-3}$ during the identified week 1 . This lies in the lower range of concentrations measured in Switzerland during winter (Lanz et al., 2009). Indeed, the relatively high temperatures $\left(-2\right.$ to $\left.22^{\circ} \mathrm{C}\right)$ observed during this campaign prevented the formation of strong inversions and the subsequent accumulation of high aerosol concentrations. In Fig. 8, the average $\mathrm{PM}_{1}$ compositions for the working days and the Sunday of week 1 15 confirm the dominical increase in the relative contribution of BC and secondary inorganics already noticed in $\mathrm{PM}_{10}$. Note that the working days included only the 27 and 28 November 2006 and 1 December 2006 here, due to the lack of AMS data during part of the 29 November 2006. However, the composition for the working days was close to the average composition for the whole campaign. Sunday 3 December 2006, on the contrary, differed from the average composition on the three Sundays, which did not show much difference compared to the average composition on the working days. The difference between working days and Sunday on week 1 was probably due to the enhanced presence of locally emitted $\mathrm{PM}_{1}$.

\subsubsection{Fine carbonaceous aerosol source apportionment}

25 Sources of organics in Massongex were investigated by factor analysis of the AMS organics mass spectra (FA-AMS) (Lanz et al., 2007; Ulbrich et al., 2009). Up to

Composition and sources of particulate matter

N. Perron et al.

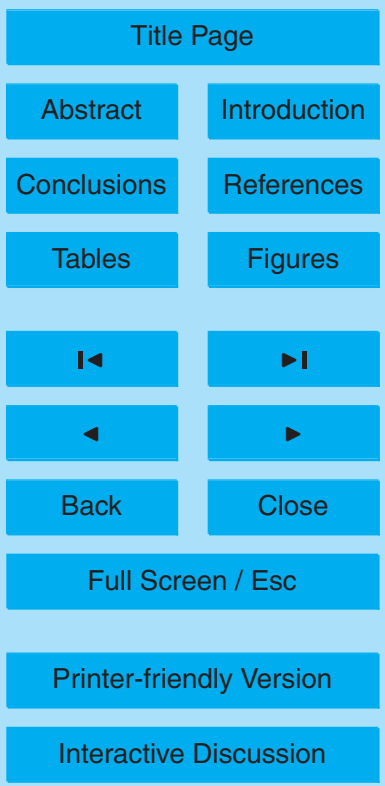


three factors could be related to meaningful organic aerosol (OA) sources, namely hydrocarbon-like OA (HOA), primary OA from wood burning (P-WBOA), and oxygenated (mostly secondary) OA (OOA) (see the discussion and Table $\mathrm{S} 2$ in the supplementary material, see http://www.atmos-chem-phys-discuss.net/10/9391/2010/

5 acpd-10-9391-2010-supplement.pdf). The most satisfying solution was obtained using the multilinear engine (ME-2: Paatero, 1999) with a degree of variability $a=0.4$ (see Lanz et al. (2008) for a discussion of a). This solution led to average OA contributions of $14 \%(9-18 \%)$ for HOA, 49\% (45-54\%) for P-WBOA and 36\% (36-37\%) for OOA, with the uncertainty ranges encompassing the different ME-2 solutions between $a=0.2$ 10 and $a=0.8$ (see supplementary material). Combining the $a=0.4$ solution with the ${ }^{14} \mathrm{C}$ results suggested that $40 \%$ of the OOA was fossil. This is comparable to the $31 \%$ found by Lanz et al. (2008) during a winter campaign at an urban background site in Zurich. Times series of the identified $\mathrm{OA}$ factors, together with $\mathrm{BC}_{\mathrm{wb}}$ and $\mathrm{BC}_{\mathrm{t}}$, and their relative contributions to the $\mathrm{PM}_{1}$ carbonaceous aerosol on the selected working days and 15 on the Sunday are presented in Fig. 9. $\mathrm{PM}_{1}$ carbonaceous concentrations are very similar for both the working days and the Sunday, due to the fact that the enhanced wood-burning emissions of $\mathrm{BC}$ and primary organics as well as the OOA production compensate the reduction in fossil emissions, especially of $\mathrm{BC}_{\mathrm{t}}$.

Average diurnal cycles of the retrieved organic components are presented in Fig. 10, along with the diurnal cycles of gaseous and particulate species. Two main concentration enhancements, one in the morning (around 06:00 a.m.-11:00 a.m. LT) and in the evening (03:00 p.m.-09:00 p.m. LT) characterise the daily cycles of $\mathrm{HOA}, \mathrm{NO}_{x}$ and $\mathrm{BC}_{\mathrm{t}}$ and likely correspond to the traffic rush hours with low vertical dilution. An additional contribution of domestic fuel heaters in the evening might be speculated. In contrast,

25 P-WBOA, AMS-potassium and $\mathrm{BC}_{\mathrm{wb}}$ show only one main increase between 04:00 p.m. and 03:00 a.m. LT. Similarly to what observed in other wood-burning-dominated locations, this probably corresponds to the increased use of domestic wood heaters in the evening (Alfarra et al., 2007; Sandradewi et al., 2008a; b; Krecl et al., 2008). The fact that, despite being determined independently, the daily patterns of $\mathrm{HOA}$ and $\mathrm{BC}_{\mathrm{t}}$

Composition and sources of particulate matter

N. Perron et al.

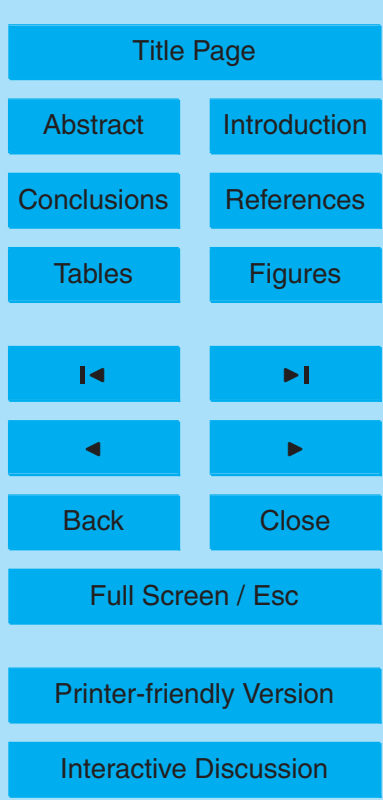

Interactive Discussion 
are similar, the same being true for P-WBOA and $\mathrm{BC}_{\mathrm{wb}}$, validates the FA-AMS and aethalometer-based methods as source apportionment tools to discriminate between the fossil and biomass-burning sources of fine organics and $\mathrm{BC}$, respectively. Further comparison of these results with those from the ${ }^{14} \mathrm{C}$ analyses will be discussed in 5 another paper (Perron et al., 2010).

The OOA diurnal cycles correlate well with those of AMS nitrate and sulphate, displaying two peaks. The first one in the beginning of the afternoon probably corresponds to the maximal light intensity, which is around 01:00 p.m. LT in winter, and to a correspondingly enhanced photochemistry. The second one might be linked to the 10 night-time oxidation (e.g. by the $\mathrm{NO}_{3}$ radical) of the organics emitted in the evening. However, the enhanced OOA concentrations in the evening may also partially stem from primary wood-burning emissions, which during the smouldering phase in the later evening can exhibit organic mass spectra that are similar to OOA (Weimer et al., 2008).

\subsubsection{Chloride}

In Fig. 11, the chloride concentrations deduced from IC on $\mathrm{PM}_{10}$ filters and from AMS measurements of the $\mathrm{PM}_{1}$ aerosol show a good agreement, indicating that the high amount of chloride mentioned in Sect. 4.1.4 is overwhelmingly coming from the fine mode. $\mathrm{AMS} \mathrm{NH}_{4}^{+}$concentrations and the total anion concentrations - i.e. $\mathrm{Cl}^{-}+\mathrm{NO}_{3}^{-}+$ $\mathrm{SO}_{4}^{2-}$ - display very similar time series, the $\mathrm{Cl}^{-}$excess peaks following exactly those of ammonium. Consequently, the presence of submicron chloride is likely to result from the neutralisation of $\mathrm{HCl}$ by gaseous ammonia $\left(\mathrm{NH}_{3}\right)$. No $\mathrm{PM}_{1}$ measurements were performed at the other stations; nevertheless it might be possible that the high $\mathrm{PM}_{10}$ chloride measured in Saxon, Sion and Brigerbad result from similar processes. Chloride may stem from incineration of domestic and industrial waste (Kaneyasu et al., 1999), or from other industrial sources, which needs further investigation.

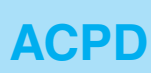

$10,9391-9430,2010$

Composition and sources of particulate matter

N. Perron et al.

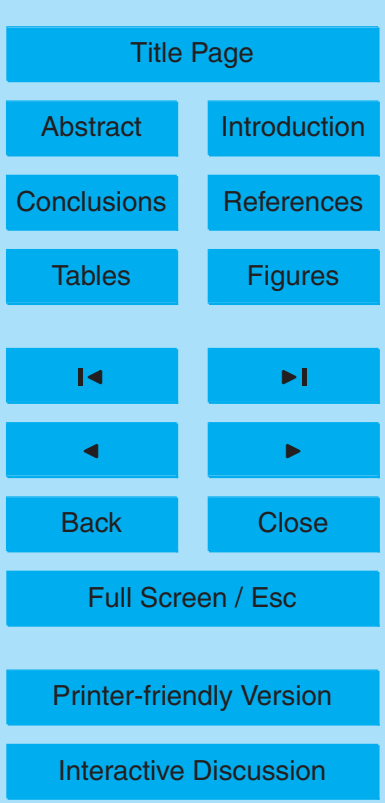




\section{Conclusions}

$\mathrm{PM}_{10}$ composition investigated at four valley-floor stations along the Swiss Rhone valley during a week of stable meteorological conditions appeared to be very similar at all sites. On working days, $\mathrm{PM}_{10}$ concentrations ranged between 25 and $82 \mathrm{\mu g} \mathrm{m}^{-3}$ and 5 were dominated by carbonaceous matter (28-38\% OM and 6-9\% EM of the $\mathrm{PM}_{10}$ ), followed by secondary inorganics (10 to 18\%) and mineral dust in about equal proportions (13 to $18 \%$ ). During these days, $\mathrm{PM}_{10}$ was mainly influenced by wood burning on the one hand and by heavy-duty traffic on the other hand. The latter source included direct exhaust emissions as well as resuspension of non-exhaust particles, and was reduced by about two thirds on the following Sunday. In Massongex, at the entrance of the valley, the $\mathrm{PM}_{1}$ aerosol as measured by an AMS and a seven-wavelength aethalometer during this week and the following two weeks consisted of organics $(45 \%)$, secondary inorganics (33\%), and black carbon (18\%). The latter stemmed mainly from traffic sources, whereas the submicron OM was composed of primary wood-burning organic 15 aerosol (P-WBOA, 45-54\%), followed by oxygenated organics (OOA, 36-37\%), and by traffic or industry-related hydrocarbon-like organics (HOA, 9-18\%) as the smallest contribution. A significant contribution of chloride (up to $12 \%$ of $\mathrm{PM}_{10}$ ) was also detected at all sites and appeared in Massongex to most probably result from so far unidentified $\mathrm{HCl}$ emissions neutralised by $\mathrm{NH}_{3}$. Public health protection would require further investigation of this source and should moreover focus on curtailing the heavy-duty traffic and biomass burning emissions.

Acknowledgements. This work was financially supported by the Canton of Valais, by the Swiss Federal Office for the Environment and by the EU project EUCAARI. We thank Pierre-Alain Moulin and François Coquoz from the Environmental Office of the Valais Canton for providing 25 us with the continuous monitoring data and with some general information about the Swiss Rhone Valley. Gratitude is also expressed to René Richter and Markus Furger for their help during the campaign.

Composition and sources of particulate matter

N. Perron et al.

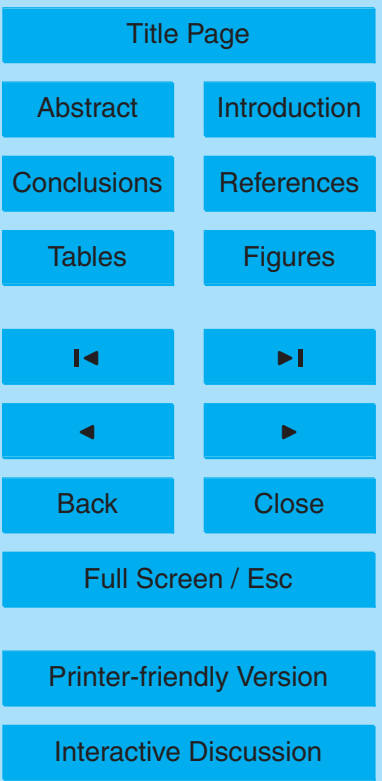




\section{References}

Aiken, A. C., DeCarlo, P. F., Kroll, J. H., Worsnop, D. R., Huffmann, J. A., Docherty, K. S., UIbrich, I. M., Mohr, C., Kimmel, J. R., Sueper, D., Sun, Y., Zhang, Q., Trimborn, A., Northway, M., Ziermann, P.J., Canagaratna, M. R., Onasch, T. B., Alfarra, M. R., Prévôt, A. S. H., Dommen, J., Duplissy, J., Metzger, A., Baltensperger, U., and Jimenez, J. L.: OM/OC ratios of primary, secondary, and ambient organic aerosols with high-resolution time-of-flight aerosol mass spectrometry, Environ. Sci. Technol., 42, 4478-4485, 2008.

Alexander, D. T. L., Crosier, P.A., and Anderson J. R.: Brown carbon spheres in East Asian outflow and their optical properties, Science, 321, 833-836, 2008.

Alfarra, M. R., Coe, H., Allan, J. D., Bower, K. N., Boudries, H., Canagaratna, M. R., Jimenez, J. L., Jayne, J. T., Garforth, A. A., Li, S.-M., and Worsnop, D. R.: Characterization of urban and rural organic particulate in the Lower Fraser Valley using two Aerodyne aerosol mass spectrometers, Atmos. Environ., 38, 5745-5758, 2004.

Alfarra, M. R., Prévôt, A. S. H., Szidat, S., Sandradewi, J., Weimer, S., Schreiber, D., Mohr, M., and Baltensperger, $\mathrm{U}$.: Identification of the mass spectral signature of organic aerosols from wood burning emissions, Environ. Sci. Technol., 41, 5770-5777, 2007.

Andreae, M. O. and Gelencsér, A.: Black carbon or brown carbon? The nature of lightabsorbing carbonaceous aerosols, Atmos. Chem. Phys., 6, 3131-3148, 2006, http://www.atmos-chem-phys.net/6/3131/2006/.

20 Aymoz, G., Jaffrezo, J. L., Chapuis, D., Cozic, J., and Maenhaut, W.: Seasonal variation of $\mathrm{PM}_{10}$ main constituents in two valleys of the French Alps. I: EC/OC fractions, Atmos. Chem. Phys., 7, 661-675, 2007, http://www.atmos-chem-phys.net/7/661/2007/.

Bae, M. S., Schauer, J. J., DeMinter, J. T., Turner, J. R., Smith, D., and Cary, R. A.: Validation of a semi-continuous instrument for elemental carbon and organic carbon using a thermaloptical method, Atmos. Environ., 38, 2885-2893, 2004.

Barmpadimos, I., Hueglin, C., Keller, J., Henne, S., and Prévôt, A. S. H.: PM 10 Trends in Switzerland from 1991 to 2008, to be submitted to Atmos. Chem. Phys. Discuss., 2010.

Birch, M. E. and Cary, R. A.: Elemental carbon-based method for monitoring occupational exposures to particulate diesel exhaust, Aerosol Sci. Tech., 25, 221-241, 1996.

Bukowiecki, N., Lienemann, P., Hill, R., Furger, M., Richard, A., Prévôt, A. S. H., Baltensperger, U., Buchmann, B., and Gehrig, R.: $\mathrm{PM}_{10}$ emission factors for non-exhaust particles gener-

\section{Composition and sources of particulate matter}

N. Perron et al.

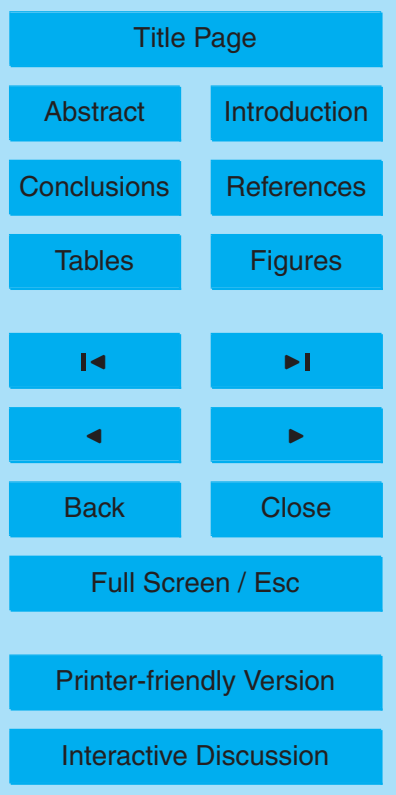


ated by road traffic in an urban street canyon and along a freeway in Switzerland, Atmos. Environ., doi:10.1016/j.atmosenv.2010.03.039, in press, 2010.

Canagaratna, M. R., Jayne, J. T., Jimenez, J. L., Allan, J. D., Alfarra, M. R., Zhang, Q., Onasch, T. B., Drewnick, F., Coe, H., Middlebrook, A., Delia, A., Williams, L. R., Trimborn, A. M., $5 \quad$ Northway, M. J., DeCarlo, P. F., Kolb, C. E., Davidovits, P., and Worsnop, D. R.: Chemical and microphysical characterization of ambient aerosols with the Aerodyne aerosol mass spectrometer, Mass Spectrom. Rev., 26, 185-222, 2007.

Caseiro, A., Marr, I. L., Claeys, M., Kasper-Giebl, A., Puxbaum, H., and Pio, C. A.: Determination of saccharides in atmospheric aerosol using anion-exchange high-performance liquid 10 chromatography and pulsed-amperometric detection, J. Chromatogr. A, 1171, 37-45, 2007.

Caseiro, A., Bauer, H., Schmidl, C., Pio, C. A., and Puxbaum, H.: Wood burning impact on $\mathrm{PM}_{10}$ in three Austrian regions, Atmos. Environ, 43, 2186-2195, 2009.

Chow, J. C., Watson, J. G., Edgerton, S. A., and Vega, E.: Chemical composition of $\mathrm{PM}_{2.5}$ and $\mathrm{PM}_{10}$ in Mexico City during winter 1997, Sci. Total Environ., 287, 177-201, 2002.

Favez, O., El Haddad, I., Piot, C., Boréave, A., Abidi, E., Marchand, N., Jaffrezo, J.-L., Besombes, J.-L., Personnaz, M.-B., Sciare, J., Wortham, H., George, C., and D'Anna, B.: Intercomparison of source apportionment models for the estimation of wood burning aerosols during wintertime in an Alpine city (Grenoble, France), Atmos. Chem. Phys. Discuss., 10, 559-613, 2010,

20 http://www.atmos-chem-phys-discuss.net/10/559/2010/.

Fraser, M. P. and Lakshmanan, K.: Using levoglucosan as a molecular marker for the longrange transport of biomass combustion aerosols, Environ. Sci. Technol., 34, 4560-4564, 2000.

Gehrig, R., Hill, M., Buchmann, B., Imhof, D., Weingartner, E., and Baltensperger, U.: Separate determination of $\mathrm{PM}_{10}$ emission factors of road traffic for tailpipe emissions and emissions from abrasion and resuspension processes, Int. J. Environ. Pollut., 22, 312-325, 2004.

Gehrig, R., Hill, M., Lienemann, P., Zwicky, C. N., Bukowiecki, N., Weingartner, E., Baltensperger, U., and Buchmann, B.: Contribution of railway traffic to local $\mathrm{PM}_{10}$ concentrations in Switzerland, Atmos. Environ., 41, 923-933, 2007.

30 Gelencsér, A., May, B., Simpson, D., Sánchez-Ochoa, A., Kasper-Giebl, A., Puxbaum, H., Caseiro, A., Pio, C., and Legrand, M.: Source apportionment of $\mathrm{PM}_{2.5}$ organic aerosol over Europe: Primary/secondary, natural/anthropogenic, and fossil/biogenic origin, J. Geophys. Res., 112, D23S04, doi:10.1029/2006JD008094, 2007.

\section{Composition and sources of particulate matter}

N. Perron et al.

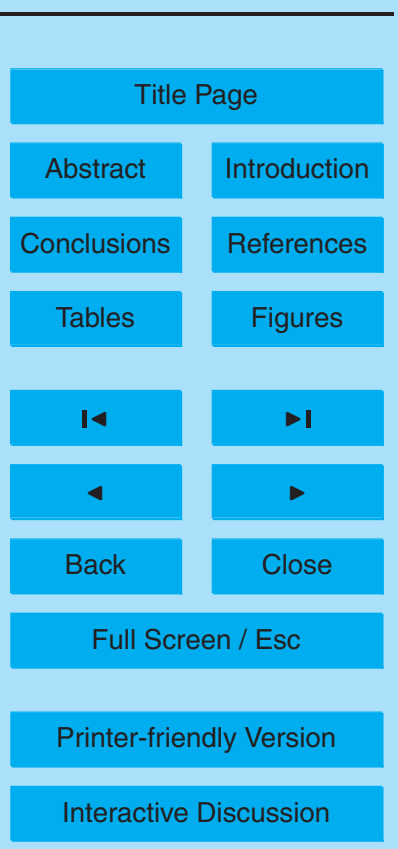


Grieshop, A. P., Logue, J. M., Donahue, N. M., and Robinson, A. L.: Laboratory investigation of photochemical oxidation of organic aerosol from wood fires 1: measurement and simulation of organic aerosol evolution, Atmos. Chem. Phys., 9, 1263-1277, 2009,

http://www.atmos-chem-phys.net/9/1263/2009/.

5 Hueglin, C., Gehrig, R., Baltensperger, U., Gysel, M., Monn, C., and Vonmont, H.: Chemical characterisation of $\mathrm{PM}_{2.5}, \mathrm{PM}_{10}$ and coarse particles at urban, near-city and rural sites in Switzerland, Atmos. Environ., 39, 637-651, 2005.

Kaneyasu, N., Yoshikado, H., Mizuno, T., Sakamoto, K., and Soufuku, M.: Chemical forms and sources of extremely high nitrate and chloride in winter aerosol pollution in the Kanto Plain 10 of Japan, Atmos. Environ., 33, 1745-1756, 1999.

Krecl, P., Ström, J., and Johansson, C.: Diurnal variation of atmospheric aerosol during the wood combustion season in Northern Sweden, Atmos. Environ., 42, 4113-4125, 2008.

Lanz, V. A., Alfarra, M. R., Baltensperger, U., Buchmann, B., Hueglin, C., and Prévôt, A. S. $\mathrm{H}$.: Source apportionment of submicron organic aerosols at an urban site by factor analytical modelling of aerosol mass spectra, Atmos. Chem. Phys., 7, 1503-1522, 2007, http://www.atmos-chem-phys.net/7/1503/2007/.

Lanz, V. A., Alfarra, M. R., Baltensperger, U., Buchmann, B., Hueglin, C., Szidat, S., Wehrli, M. N., Wacker, L., Weimer, S., Caseiro, A., Puxbaum, H., and Prévôt, A. S. H.: Source attribution of submicron organic aerosols during wintertime inversions by advanced factor analysis of aerosol mass spectra, Environ. Sci. Technol., 42, 214-220, 2008.

Lanz, V. A., Prévôt, A. S. H., Alfarra, M. R., Mohr, C., DeCarlo, P. F., Weimer, S., Gianini, M. F. D., Hueglin, C., Schneider, J., Favez, O., D’Anna, B., George, C., and Baltensperger, U.: Characterization of aerosol chemical composition by aerosol mass spectrometry in Central Europe: an overview, Atmos. Chem. Phys. Discuss., 9, 24985-25021, 2009, http://www.atmos-chem-phys-discuss.net/9/24985/2009/.

Latzin, P., Röösli, M., Huss, A., Kuehni, C. E., and Frey, U.: Air pollution during pregnancy and lung functions in newborns: a birth cohort study. Eur. Respir. J., 33, 594-603, 2009.

Lukács, H., Gelencsér, A., Hammer, H., Puxbaum, H., Pio, C., Legrand, M., Kasper-Giebl, A., Handler, M., Limbeck, A., Simpson, D., and Preunkert, S.: Seasonal trends and possible sources of brown carbon based on 2-year aerosol measurements at six sites in Europe, J. Geophys. Res., 112, D23S18, doi:10.1029/2006JD008151, 2007.

Marenco, F., Bonasoni, P., Calzolari, F., Ceriani, M., Chiari, M., Cristofanelli, P., D’Alessandro, A., Fermo, P., Lucarelli, F., Mazzei, F., Nava, S., Piazzalunga, A., Prati, P., Valli, G., and

\section{Composition and sources of particulate matter}

N. Perron et al.

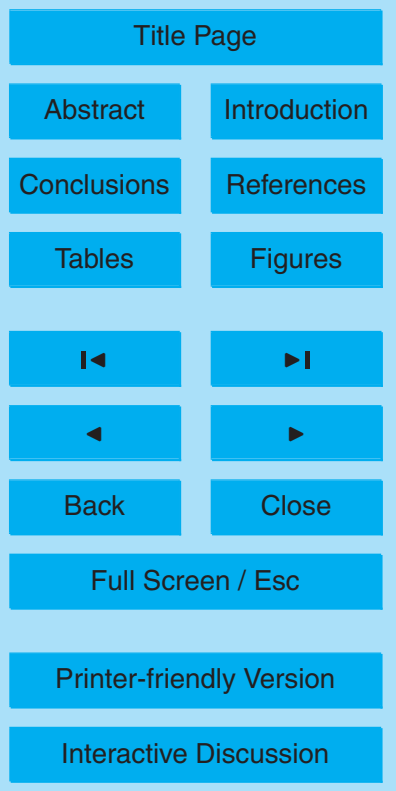


Vecchi, R.: Characterization of atmospheric aerosols at Monte Cimone, Italy, during summer 2004: source apportionment and transport mechanisms, J. Geophys. Res., 111, D24202, doi:10.1029/2006JD007145, 2006.

Miller, K. A., Siscovick, D. S., Sheppard, L., Shepherd, K., Sullivan, J. H., Anderson, G. L., and

$5 \quad$ Kaufman, J. D.: Long-term exposure to air pollution and incidence of cardiovascular events in women, New Engl. J. Med., 356, 447-458, 2007.

Mokdad, A. H., Marks, J. S., Stroup, D. F., and Gerberding, J. L.: Actual causes of death in the United States, 2000, J. Am. Med. Assoc., 291, 1238-1245, 2004.

Moosmüller, H., Chakrabarty, R. K., and Arnott, W. P.: Aerosol light absorption and its measurement: A review, J. Quant. Spectrosc. Ra., 110, 844-878, 2009.

Morris, R. D.: Airborne particulates and hospital admissions for cardiovascular disease: A quantitative review of the evidence, Environ. Health Persp., 109, 495-500, 2001.

Paatero, P. and Tapper, U.: Positive matrix factorization: a nonnegative factor model with optimal utilization of error estimates of data values, Environmetrics, 5, 111-126, 1994.

Paatero, P.: The multilinear engine - A table-driven, least squares program for solving multilinear problems, including the n-way parallel factor analysis model, J. Comput. Graph. Stat., 8, 854-888, 1999.

Pacyna, J. M. and Pacyna, E. G.: An assessment of global and regional emissions of trace metals to the atmosphere from anthropogenic sources worldwide, Environ. Rev., 9, 269298, 2001.

Perron, N., Sandradewi, J., Prévôt A. S. H., Alfarra, M. R., Szidat, S., Wehrli, M. N., Ruff, M., Fahrni, S., Weimer, S., Lanz, V. A., Weingartner, E., Caseiro, A., Puxbaum, H., Wacker, L., and Baltenperger, U.: Comparison of several source apportionment methods for woodburning particulate mass, to be submitted to Atmos. Chem. Phys. Discuss., 2010.

Prévôt, A. S. H., Dommen, J., Baumle, M., and Furger, M.: Diurnal Variations of volatile organic compounds and local circulation systems in an Alpine valley, Atmos. Environ., 34, 14131423, 2000.

Putaud, J. P., Raes, F., Van Dingenen, R., Bruggemann, E., Facchini, M. C., Decesari, S., Fuzzi, S., Gehrig, R., Huglin, C., Laj, P., Lorbeer, G., Maenhaut, W., Mihalopoulos, N., MulIler, K., Querol, X., Rodriguez, S., Schneider, J., Spindler, G., ten Brink, H., Torseth, K., and Wiedensohler, A.: European aerosol phenomenology-2: chemical characteristics of particulate matter at kerbside, urban, rural and background sites in Europe, Atmos. Environ., 38, 2579-2595, 2004.

Composition and sources of particulate matter

N. Perron et al.

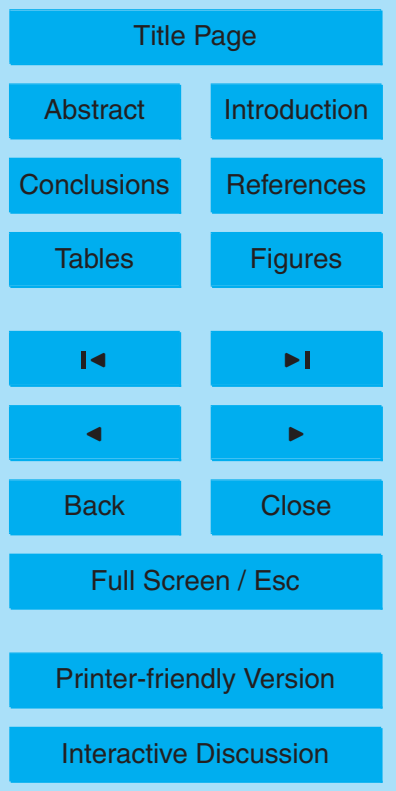

Interactive Discussion 
Puxbaum, H., Caseiro, A., Sánchez-Ochoa, A., Kasper-Giebl, A., Claeys, M., Gelencsér, A., Legrand, M., Preunkert, S., and Pio, C.: Levoglucosan levels at background sites in Europe for assessing the impact of biomass combustion on the European aerosol background, J. Geophys. Res., 112, D23S05, doi:10.1029/2006JD008114, 2007.

5 Reid, J. S., Eck, T. F., Christopher, S. A., Koppmann, R., Dubovik, O., Eleuterio, D. P., Holben, B. N., Reid, E. A., and Zhang, J.: A review of biomass burning emissions part III: intensive optical properties of biomass burning particles, Atmos. Chem. Phys., 5, 827-849, 2005, http://www.atmos-chem-phys.net/5/827/2005/.

Résival: Qualité de l'air en Valais 2006: http://www.vs.ch/Press/DS_324/ PUBL-2007-06-22-12320/fr/ResivalRapport2006.pdf, last access: 29 March 2010.

Röössli, M., Künzli, N., Braun-Fahrländer, C., and Egger, M.: Years of life lost attributable to air pollution in Switzerland: dynamic exposure-response model, Int. J. Epidemiol., 34, 10291035, 2005.

Ruff, M., Wacker, L., Gäggeler, H. W., Suter, M., Synal, H. A., and Szidat, S.: A gas ion source for radiocarbon measurements at $200 \mathrm{kV}$, Radiocarbon, 49, 307-314, 2007.

Sandradewi, J., Prévôt, A. S. H., Weingartner, E., Schmidhauser, R., Gysel, M., and Baltensperger, U.: A study of wood burning and traffic aerosols in an Alpine valley using a multi-wavelength aethalometer, Atmos. Environ., 42, 101-112, 2008a.

Sandradewi, J., Prévôt, A. S. H., Szidat, S., Perron, N., Alfarra, M. R., Lanz, V. A., Weingartner, E., and Baltensperger, U.: Using aerosol light absorption measurements for the quantitative determination of wood burning and traffic emission contributions to particulate matter, Environ. Sci. Technol., 42, 3316-3323, 2008b.

Schmidl, C., Marr, L. L., Caseiro, A., Kotianova, P., Berner, A., Bauer, H., Kasper-Giebl, A., and Puxbaum, $\mathrm{H} .:$ Chemical characterisation of fine particle emissions from wood stove combustion of common woods growing in mid-European Alpine regions, Atmos. Environ., 42, 126-141, 2008.

Schneider, J., Weimer, S., Drewnick, F., Borrmann, S., Helas, G., Gwaze, P., Schmid, O., Andreae, M. O., and Kirchner, U.: Mass Spectrometric analysis and aerodynamic properties of various types of combustion-related aerosol particles, Int. J. Mass Spectrom., 258, 37-49, $30 \quad 2006$

Simoneit, B. R. T.: A review of biomarker compounds as source indicators and tracers for air pollution, Environ. Sci. Pollut. R., 6, 159-169, 1999.

Stuiver, M. and Polach, H. A.: Reporting of ${ }^{14} \mathrm{C}$ Data - Discussion, Radiocarbon, 19, 355-363,

Composition and sources of particulate matter

N. Perron et al.

Title Page

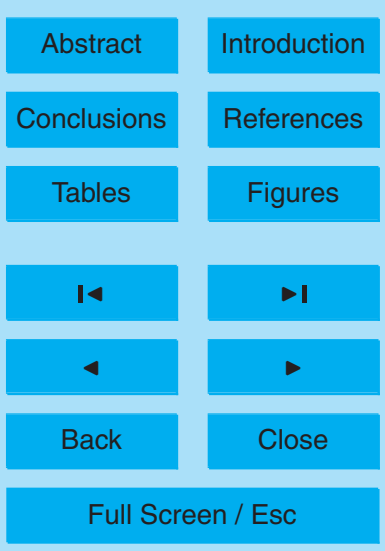

Printer-friendly Version

Interactive Discussion 
1977.

Szidat, S., Jenk, T. M., Gäggeler, H. W., Synal, H.-A, Fisseha, R., Baltensperger, U., Kalberer, M., Samburova, V., Wacker, L., Saurer, M., Schwikowski, M., and Hajdas, I.: Source apportionment of aerosols by ${ }^{14} \mathrm{C}$ measurements in different carbonaceous particle fractions,

5 Radiocarbon, 46, 475-484, 2004.

Szidat, S., Jenk, T. M., Synal, H. A., Kalberer, M., Wacker, L., Hajdas, I., Kasper-Giebl, A., and Baltensperger, U.: Contributions of fossil fuel, biomass-burning, and biogenic emissions to carbonaceous aerosols in Zurich as traced by ${ }^{14} \mathrm{C}$. J. Geophys. Res., 111, D07206, doi:10.1029/2005JD006590, 2006.

10 Szidat, S., Prévôt, A. S. H., Sandradewi, J., Alfarra, M. R., Synal, H. -A., Wacker, L., and Baltensperger, U.: Dominant impact of residential wood burning on particulate matter in Alpine valleys during winter, Geophys. Res. Lett., 34, L05820, doi:10.1029/2006GL028325, 2007.

Szidat, S., Ruff, M., Perron, N., Wacker, L., Synal, H.-A., Hallquist, M., Shannigrahi, A. S., Yttri, K. E., Dye, C., and Simpson, D.: Fossil and non-fossil sources of organic carbon (OC) and elemental carbon (EC) in Göteborg, Sweden, Atmos. Chem. Phys., 9, 1521-1535, 2009, http://www.atmos-chem-phys.net/9/1521/2009/.

Thorpe, A. and Harrison, R. M.: Sources and properties of non-exhaust particulate matter from road traffic: A review, Sci. Total Environ., 400, 270-282, 2008.

20 Ulbrich, I. M., Canagaratna, M. R., Zhang, Q., Worsnop, D. R., and Jimenez, J. L.: Interpretation of organic components from Positive Matrix Factorization of aerosol mass spectrometric data, Atmos. Chem. Phys., 9, 2891-2918, 2009, http://www.atmos-chem-phys.net/9/2891/2009/.

Weimer, S., Alfarra, M. R., Schreiber, D., Mohr, M., Prévôt, A. S. H., and Baltensperger, U.: Organic aerosol mass spectral signatures from wood burning emissions: Influence of burning conditions and wood type, J. Geophys. Res., 113, D10304, doi:10.1029/2007JD009309, 2008.

Weingartner, E., Saathoff, H., Schnaiter, M., Streit, N., Bitnar, B., and Baltensperger, U.: Absorption of light by soot particles: determination of the absorption coefficient by means of

30 aethalometers, J. Aerosol Sci., 34, 1445-1463, 2003.

WHO: WHO Air quality guidelines for particulate matter, ozone, nitrogen dioxide and sulfur dioxide, global update 2005, summary of risk assessment, World Health Organization, document WHO/SDE/PHE/OEH/06.02, Geneva, 2006.

\section{Composition and sources of particulate matter}

N. Perron et al.

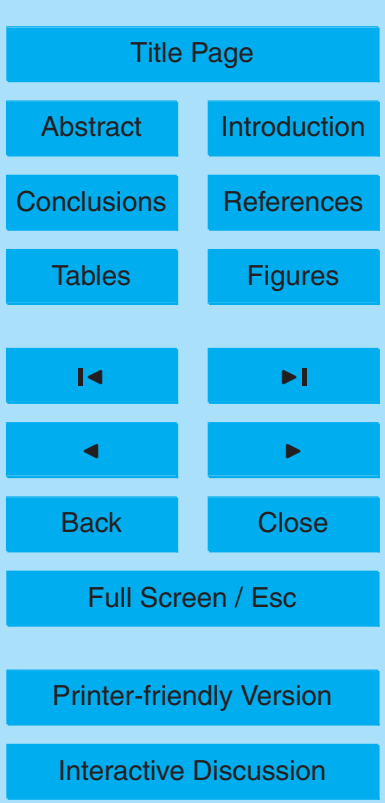




\section{ACPD}

$10,9391-9430,2010$

Composition and sources of

\section{particulate matter}

N. Perron et al.

Table 1. Description of the four sampling sites: coordinates, altitudes (meter above sea level, ma.s.l.), site characteristics and traffic intensity.

\begin{tabular}{lllll}
\hline & Massongex (MAS) & Saxon (SAX) & Sion (SIO) & Brigerbad (BRI) \\
\hline Coordinates & $46^{\circ} 14^{\prime} 35^{\prime \prime} \mathrm{N}, 6^{\circ} 08^{\prime} 06^{\prime \prime} \mathrm{E}$ & $46^{\circ} 08^{\prime} 24^{\prime \prime} \mathrm{N}, 7^{\circ} 08^{\prime} 57^{\prime \prime} \mathrm{E}$ & $46^{\circ} 13^{\prime} 57^{\prime \prime} \mathrm{N}, 7^{\circ} 21^{\prime} 24^{\prime \prime} \mathrm{E}$ & $46^{\circ} 17^{\prime} 58^{\prime \prime} \mathrm{N}, 7^{\circ} 55^{\prime} 02^{\prime \prime} \mathrm{E}$ \\
Altitude & $400 \mathrm{~m}$ a.s.I. & $460 \mathrm{~m}$ a.s.I. & $505 \mathrm{~m}$ a.s.I. & $650 \mathrm{~m}$ a.s.I. \\
Site & Rural zone & Rural zone & Town centre & Rural zone \\
Characteristics & Industrial proximity & Exposed to traffic & Exposed to traffic & $\begin{array}{c}\text { Exposed to traffic } \\
\text { Industrial proximity }\end{array}$ \\
\cline { 3 - 4 } & & Downwind from industries & & Medium \\
\hline
\end{tabular}

Title Page

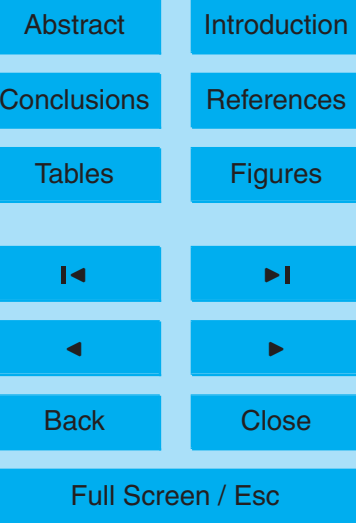

Printer-friendly Version

Interactive Discussion 
Table 2. Instruments and analytical techniques used during the campaign.

\section{ACPD}

\begin{tabular}{|c|c|c|c|c|c|}
\hline Instrument/Method & $\begin{array}{l}\text { Instrument/Method } \\
\text { characteristics }\end{array}$ & Parameters & Time resolution & Inlet & Stations \\
\hline $\begin{array}{l}\text { Aerosol mass } \\
\text { spectrometer } \\
\text { (AMS) }\end{array}$ & $\begin{array}{l}\text { Aerodyne Research Inc., } \\
\text { Massachusetts, USA De- } \\
\text { scribed in Canagartna et } \\
\text { al., } 2007 .\end{array}$ & $\begin{array}{l}\mathrm{Cl}^{-}, \mathrm{NO}_{3}^{-}, \mathrm{SO}_{4}^{2-}, \mathrm{NH}_{4}^{+} \text {, or- } \\
\text { ganic mass in } \mathrm{PM}_{1} \text {. }\end{array}$ & $5 \mathrm{~min}$ & $\mathrm{PM}_{1}$ & Massongex \\
\hline TEOM & $\begin{array}{l}\text { Rupprecht \& Pataschnick } \\
\text { Co., Inc., USA, Series } \\
\text { 1400a. }\end{array}$ & Particle mass. & $30 \mathrm{~min}$ & & \\
\hline $\begin{array}{l}\text { Off-line thermo- } \\
\text { optical OC/EC }\end{array}$ & $\begin{array}{l}\text { Sunset Laboratory, Inc., } \\
\text { USA, type RT- } \\
\text { 3080/NIOSH-like } \\
\text { protocol. }\end{array}$ & OC/EC. & & & \\
\hline${ }^{14} \mathrm{C}$ analysis & $\begin{array}{l}\text { Described in Szidat et al., } \\
2004,2006 .\end{array}$ & $\begin{array}{l}\text { Fossil/non-fossil OC and } \\
\text { EC. }\end{array}$ & & & \\
\hline $\begin{array}{l}\text { lon } \\
\text { chromatography }\end{array}$ & $\begin{array}{l}\text { Described in the EMEP } \\
\text { manual for sampling } \\
\text { and chemical analysis: } \\
\text { http://tarantula.nilu.no/ } \\
\text { projects/ccc/manual. }\end{array}$ & 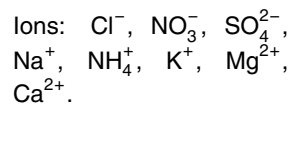 & & & \\
\hline
\end{tabular}

$10,9391-9430,2010$

\section{Composition and sources of particulate matter}

\section{N. Perron et al.}

Title Page

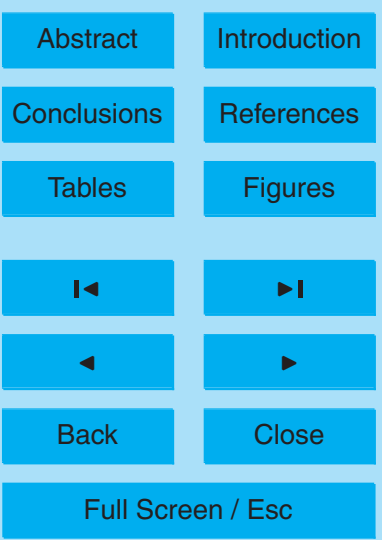

Printer-friendly Version

Interactive Discussion 
Table 3. Absolute concentrations (right) and relative contributions normalised to the total $\mathrm{PM}_{10}$ mass concentrations (left) for the analysed $\mathrm{PM}_{10}$ components at Massongex, Saxon, Sion and Brigerbad. "Working days" correspond to the average for the days 27 and 28 November and 1 December 2006, and "Sunday" represents the 3 December 2006. The rest was calculated as the difference between the $\mathrm{PM}_{10}$ concentrations given by the beta-meter and the sum of the identified components. b.d.I. stands for "below detection limit".

\begin{tabular}{|c|c|c|c|c|c|c|c|c|c|c|c|c|c|c|c|c|}
\hline & \multicolumn{8}{|c|}{$\mathrm{PM}_{10}$ concentrations $\left(\mu \mathrm{g} \mathrm{m}^{-3}\right)$} & \multicolumn{8}{|c|}{ Contributions to $\mathrm{PM}_{10}$} \\
\hline & \multicolumn{2}{|c|}{ Massongex } & \multicolumn{2}{|c|}{ Saxon } & \multicolumn{2}{|c|}{ Sion } & \multicolumn{2}{|c|}{ Brigerbad } & \multicolumn{2}{|c|}{ Massongex } & \multicolumn{2}{|c|}{ Saxon } & \multicolumn{2}{|c|}{ Sion } & \multicolumn{2}{|c|}{ Brigerbad } \\
\hline & $\begin{array}{l}\text { Working } \\
\text { days }\end{array}$ & Sunday & $\begin{array}{l}\text { Working } \\
\text { days }\end{array}$ & Sunday & $\begin{array}{l}\text { Working } \\
\text { days }\end{array}$ & Sunday & $\begin{array}{l}\text { Working } \\
\text { days }\end{array}$ & Sunday & $\begin{array}{l}\text { Working } \\
\text { days }\end{array}$ & Sunday & $\begin{array}{l}\text { Working } \\
\text { days }\end{array}$ & Sunday & $\begin{array}{l}\text { Working } \\
\text { days }\end{array}$ & Sunday & $\begin{array}{l}\text { Working } \\
\text { days }\end{array}$ & Sunday \\
\hline $\mathrm{PM}_{10}$ & 40.23 & 25.98 & 41.33 & 28.21 & 41.68 & 27.07 & 61.27 & 34.09 & & & & & & & & \\
\hline $\mathrm{EM}_{\text {tot }}$ & 2.80 & 1.52 & 3.88 & 1.88 & 4.08 & 2.13 & 4.94 & 1.98 & $7.0 \%$ & $5.8 \%$ & $9.4 \%$ & $6.6 \%$ & $9.8 \%$ & $7.9 \%$ & $8.1 \%$ & $5.8 \%$ \\
\hline $\mathrm{OM}_{\text {tot }}$ & 12.26 & 10.76 & 16.73 & 13.78 & 14.36 & 12.72 & 18.48 & 15.37 & $30.5 \%$ & $41.4 \%$ & $40.5 \%$ & $48.8 \%$ & $34.5 \%$ & $47.0 \%$ & $30.2 \%$ & $45.1 \%$ \\
\hline $\mathrm{EM}_{\mathrm{f}}$ & 2.12 & 0.89 & 3.03 & 1.11 & 3.53 & 1.57 & 4.04 & 1.05 & $5.3 \%$ & $3.4 \%$ & $7.3 \%$ & $3.9 \%$ & $8.5 \%$ & $5.8 \%$ & $6.6 \%$ & $3.1 \%$ \\
\hline $\mathrm{EM}_{\mathrm{wb}}$ & 0.69 & 0.62 & 0.85 & 0.77 & 0.55 & 0.57 & 0.90 & 0.93 & $1.7 \%$ & $2.4 \%$ & $2.1 \%$ & $2.7 \%$ & $1.3 \%$ & $2.1 \%$ & $1.5 \%$ & $2.7 \%$ \\
\hline $\mathrm{OM}_{\mathrm{f}}$ & 2.89 & 1.67 & 3.85 & 1.88 & 6.03 & 3.01 & 6.81 & 3.22 & $7.2 \%$ & $6.4 \%$ & $9.3 \%$ & $6.7 \%$ & $14.5 \%$ & $11.1 \%$ & $11.1 \%$ & $9.4 \%$ \\
\hline $\mathrm{OM}_{\mathrm{nf}}$ & 9.37 & 9.09 & 12.88 & 11.90 & 8.33 & 9.71 & 11.68 & 12.15 & $23.3 \%$ & $35.0 \%$ & $31.2 \%$ & $42.2 \%$ & $20.0 \%$ & $35.9 \%$ & $19.1 \%$ & $35.7 \%$ \\
\hline $\mathrm{Cl}^{-1}$ & 1.13 & 1.41 & 1.86 & 3.34 & 2.59 & 2.79 & 1.52 & 2.73 & $2.8 \%$ & $5.4 \%$ & $4.5 \%$ & $11.8 \%$ & $6.2 \%$ & $10.3 \%$ & $2.5 \%$ & $8.0 \%$ \\
\hline $\mathrm{NO}_{3}^{-}$ & 3.52 & 4.69 & 3.31 & 3.60 & 3.19 & 3.94 & 2.78 & 4.10 & $8.7 \%$ & $18.0 \%$ & $8.0 \%$ & $12.8 \%$ & $7.7 \%$ & $14.5 \%$ & $4.5 \%$ & $12.0 \%$ \\
\hline $\mathrm{SO}_{4}^{2-}$ & 2.53 & 2.29 & 2.29 & 1.08 & 1.90 & 1.34 & 2.19 & 2.32 & $6.3 \%$ & $8.8 \%$ & $5.5 \%$ & $3.8 \%$ & $4.6 \%$ & $5.0 \%$ & $3.6 \%$ & $6.8 \%$ \\
\hline $\mathrm{NH}_{4}^{+}$ & 1.82 & 2.62 & 2.02 & 2.82 & 2.22 & 2.65 & 1.51 & 3.16 & $4.5 \%$ & $10.1 \%$ & $4.9 \%$ & $10.0 \%$ & $5.3 \%$ & $9.8 \%$ & $2.5 \%$ & $9.3 \%$ \\
\hline $\mathrm{Na}^{+}$ & 0.10 & 0.06 & 0.12 & 0.06 & 0.15 & 0.09 & 0.18 & 0.09 & $0.3 \%$ & $0.2 \%$ & $0.3 \%$ & $0.2 \%$ & $0.3 \%$ & $0.3 \%$ & $0.3 \%$ & $0.3 \%$ \\
\hline $\mathrm{K}_{2} \mathrm{O}$ & 1.02 & 0.92 & 0.64 & 0.42 & 0.62 & 0.44 & 1.18 & 0.58 & $2.5 \%$ & $3.6 \%$ & $1.5 \%$ & $1.5 \%$ & $1.5 \%$ & $1.6 \%$ & $1.9 \%$ & $1.7 \%$ \\
\hline $\mathrm{MgO}$ & 0.37 & 0.11 & 0.31 & 0.14 & 0.41 & 0.18 & 0.53 & 0.27 & $0.9 \%$ & $0.4 \%$ & $0.8 \%$ & $0.5 \%$ & $1.0 \%$ & $0.7 \%$ & $0.9 \%$ & $0.8 \%$ \\
\hline $\mathrm{CaO}$ & 0.68 & 0.46 & 1.09 & 0.44 & 1.77 & 0.66 & 2.50 & 0.55 & $1.7 \%$ & $1.8 \%$ & $2.6 \%$ & $1.6 \%$ & $4.3 \%$ & $2.4 \%$ & $4.1 \%$ & $1.6 \%$ \\
\hline $\mathrm{Fe}_{2} \mathrm{O}_{3}$ & 1.03 & 0.39 & 1.28 & 0.53 & 1.67 & 0.87 & 2.73 & 1.04 & $2.6 \%$ & $1.5 \%$ & $3.1 \%$ & $1.9 \%$ & $4.0 \%$ & $3.2 \%$ & $4.5 \%$ & $3.1 \%$ \\
\hline $\mathrm{Al}_{2} \mathrm{O}_{3}$ & 0.68 & 0.22 & 0.56 & 0.21 & 0.70 & 0.27 & 1.03 & 0.32 & $1.7 \%$ & $0.8 \%$ & $1.4 \%$ & $0.7 \%$ & $1.7 \%$ & $1.0 \%$ & $1.7 \%$ & $0.9 \%$ \\
\hline $\mathrm{SiO}_{2}$ & 2.61 & 0.84 & 2.16 & 0.81 & 2.68 & 1.03 & 3.97 & 1.23 & $6.5 \%$ & $3.2 \%$ & $5.2 \%$ & $2.9 \%$ & $6.4 \%$ & $3.8 \%$ & $6.5 \%$ & $3.6 \%$ \\
\hline $\mathrm{Pb}$ & 0.023 & 0.014 & 0.013 & 0.008 & 0.025 & 0.002 & 0.013 & 0.008 & $0.06 \%$ & $0.05 \%$ & $0.03 \%$ & $0.03 \%$ & $0.06 \%$ & $0.01 \%$ & $0.02 \%$ & $0.02 \%$ \\
\hline $\mathrm{Zn}$ & 0.051 & 0.023 & 0.245 & 0.034 & 0.102 & 0.065 & 0.084 & 0.072 & $0.13 \%$ & $0.09 \%$ & $0.59 \%$ & $0.12 \%$ & $0.24 \%$ & $0.24 \%$ & $0.14 \%$ & $0.21 \%$ \\
\hline $\mathrm{Cu}$ & 0.010 & 0.003 & 0.024 & 0.009 & 0.035 & 0.022 & 0.047 & 0.014 & $0.03 \%$ & $0.01 \%$ & $0.06 \%$ & $0.03 \%$ & $0.08 \%$ & $0.08 \%$ & $0.08 \%$ & $0.04 \%$ \\
\hline $\mathrm{Ni}$ & 0.001 & b.d.l. & 0.001 & b.d.l. & 0.008 & b.d.I. & 0.004 & b.d.l. & $0.00 \%$ & b.d.l. & $0.00 \%$ & b.d.l. & $0.02 \%$ & b.d.I. & $0.01 \%$ & b.d.I. \\
\hline $\mathrm{Cr}$ & 0.006 & 0.001 & 0.003 & 0.001 & 0.005 & 0.003 & 0.008 & 0.003 & $0.02 \%$ & $0.00 \%$ & $0.01 \%$ & $0.00 \%$ & $0.01 \%$ & $0.01 \%$ & $0.01 \%$ & $0.01 \%$ \\
\hline $\mathrm{Mn}$ & 0.015 & 0.004 & 0.015 & 0.006 & 0.019 & 0.008 & 0.030 & 0.010 & $0.04 \%$ & $0.02 \%$ & $0.04 \%$ & $0.02 \%$ & $0.05 \%$ & $0.03 \%$ & $0.05 \%$ & $0.03 \%$ \\
\hline P & 0.025 & 0.022 & 0.056 & 0.035 & 0.045 & 0.025 & 0.036 & 0.029 & $0.06 \%$ & $0.09 \%$ & $0.14 \%$ & $0.13 \%$ & $0.11 \%$ & $0.09 \%$ & $0.06 \%$ & $0.08 \%$ \\
\hline Rest & 9.53 & 0.00 & 4.73 & 0.00 & 5.10 & 0.00 & 17.50 & 0.22 & $23.7 \%$ & $0.0 \%$ & $11.4 \%$ & $0.0 \%$ & $12.2 \%$ & $0.0 \%$ & $28.6 \%$ & $0.6 \%$ \\
\hline
\end{tabular}

$10,9391-9430,2010$

Composition and sources of

\section{particulate matter}

N. Perron et al.

Title Page

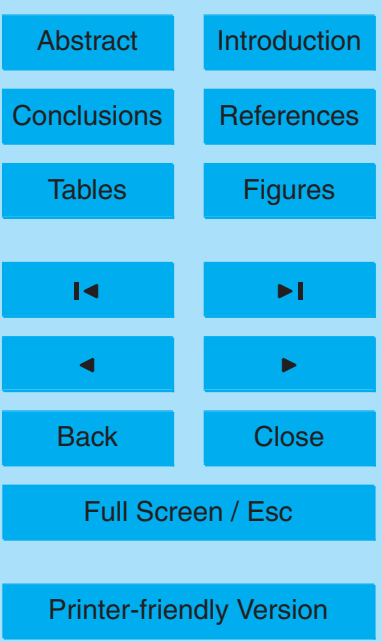

Interactive Discussion 


\section{ACPD}

10, 9391-9430, 2010

\section{Composition and sources of \\ particulate matter}

Table 4. Pearson correlation coefficients $(r)$ between the respectively fossil and non-fossil fractions of $E M\left(E M_{f}\right.$ and $\left.E M_{w b}\right)$ and the other identified $\mathrm{PM}_{10}$ components for the four stations taken together ( $\mathrm{n}=23$ samples). Significant correlations are indicated in bold with the following levels of confidence $\alpha$ : $99 \%<\alpha<99.9 \%{ }^{\mathrm{a}}, \alpha>99.9 \%{ }^{\mathrm{b}}$. ${ }^{*}$ The station of Saxon was dismissed owing to local emissions of $\mathrm{Zn}$ from a galvanization plant $5 \mathrm{~km}$ upwind from the station $(n=18$ remaining samples). ${ }^{* *}$ The station of Massongex was dismissed ( $n=15$ remaining samples). Correlation coefficients including Massongex amount to $r=0.63$ between $\mathrm{EM}_{\mathrm{f}}$ and $\mathrm{Mg}$ and to $r=0.58$ between $\mathrm{EM}_{\mathrm{f}}$ and $\mathrm{Al}$, respectively $(95 \%<\alpha<99 \%$ for both). However, no industrial sources of $\mathrm{Al}$ and $\mathrm{Mg}$ could be clearly identified around Massongex.

N. Perron et al.

\begin{tabular}{lrrrrrrrrrrrrrrrrrrr}
\hline & $\mathrm{OM}_{\mathrm{f}}$ & $\mathrm{OM}_{\mathrm{nf}}$ & $\mathrm{Cl}^{-}$ & $\mathrm{NO}_{3}^{-}$ & $\mathrm{SO}_{4}^{2-}$ & $\mathrm{NH}_{4}^{+}$ & $\mathrm{Ca}$ & $\mathrm{Al}^{\star \star}$ & $\mathrm{Mg}^{\star \star}$ & $\mathrm{Fe}$ & $\mathrm{Na}$ & $\mathrm{K}$ & $\mathrm{Cu}$ & $\mathrm{Zn}$ & $\mathrm{Mn}$ & $\mathrm{Cr}$ & $\mathrm{Ni}$ & $\mathrm{P}$ & $\mathrm{Pb}$ \\
\hline $\mathrm{EM}_{\mathrm{f}}$ & $0.92^{\mathrm{b}}$ & 0.39 & 0.23 & -0.02 & 0.42 & 0.03 & $\mathbf{0 . 9 0 ^ { \mathrm { b } }}$ & $\mathbf{0 . 8 8 ^ { \mathrm { b } }}$ & $\mathbf{0 . 8 6}^{\mathrm{b}}$ & $\mathbf{0 . 8 3}^{\mathrm{b}}$ & $\mathbf{0 . 7 2}$ & $\mathbf{0 . 5 3}^{\mathrm{a}}$ & $\mathbf{0 . 8 8}^{\mathrm{b}}$ & $\mathbf{0 . 8 6}^{\mathrm{b}}$ & $\mathbf{0 . 8 2}^{\mathrm{b}}$ & $\mathbf{0 . 6 8}^{\mathrm{b}}$ & $\mathbf{0 . 6 4}^{\mathrm{a}}$ & $\mathbf{0 . 5 8}^{\mathrm{a}}$ & 0.43 \\
$\mathrm{EM}_{\mathrm{wb}}$ & 0.38 & $\mathbf{0 . 9 1 ^ { \mathrm { b } }}$ & 0.24 & 0.48 & 0.49 & 0.35 & 0.31 & 0.07 & 0.15 & 0.41 & 0.25 & 0.48 & 0.45 & 0.44 & 0.37 & 0.23 & -0.08 & 0.38 & 0.07
\end{tabular}

\section{Full Screen / Esc}

Printer-friendly Version

ctive Discussion

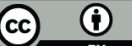




\section{ACPD}

$10,9391-9430,2010$
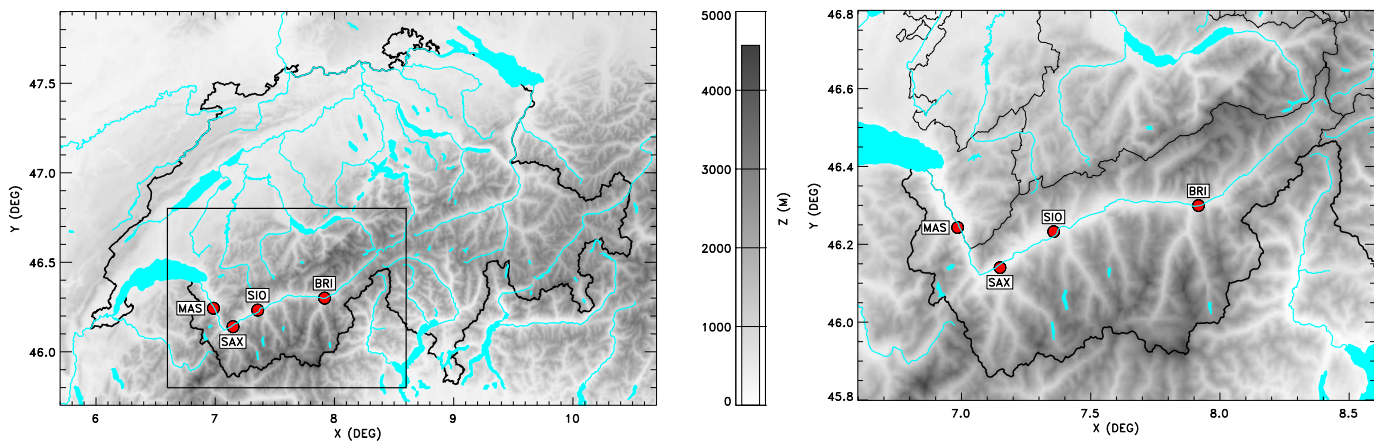

Composition and sources of

\section{particulate matter}

N. Perron et al.

Fig. 1. Geographical situation within Switzerland (left) and within the Canton Valais (right) of the four $\mathrm{PM}_{10}$ sampling sites on the floor of the Swiss Rhone valley: Massongex (MAS), Saxon (SAX), Sion (SIO) and Brigerbad (BRI). @2009 Swisstopo (JD082777).

Title Page

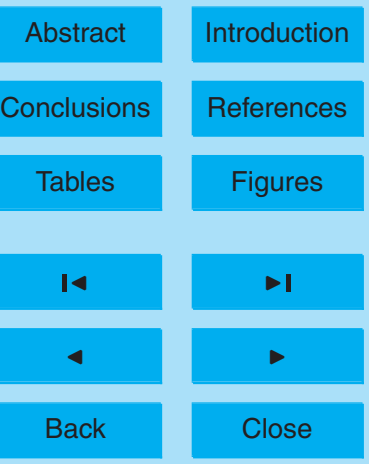

Full Screen / Esc

Printer-friendly Version

Interactive Discussion 


\section{ACPD}

$10,9391-9430,2010$
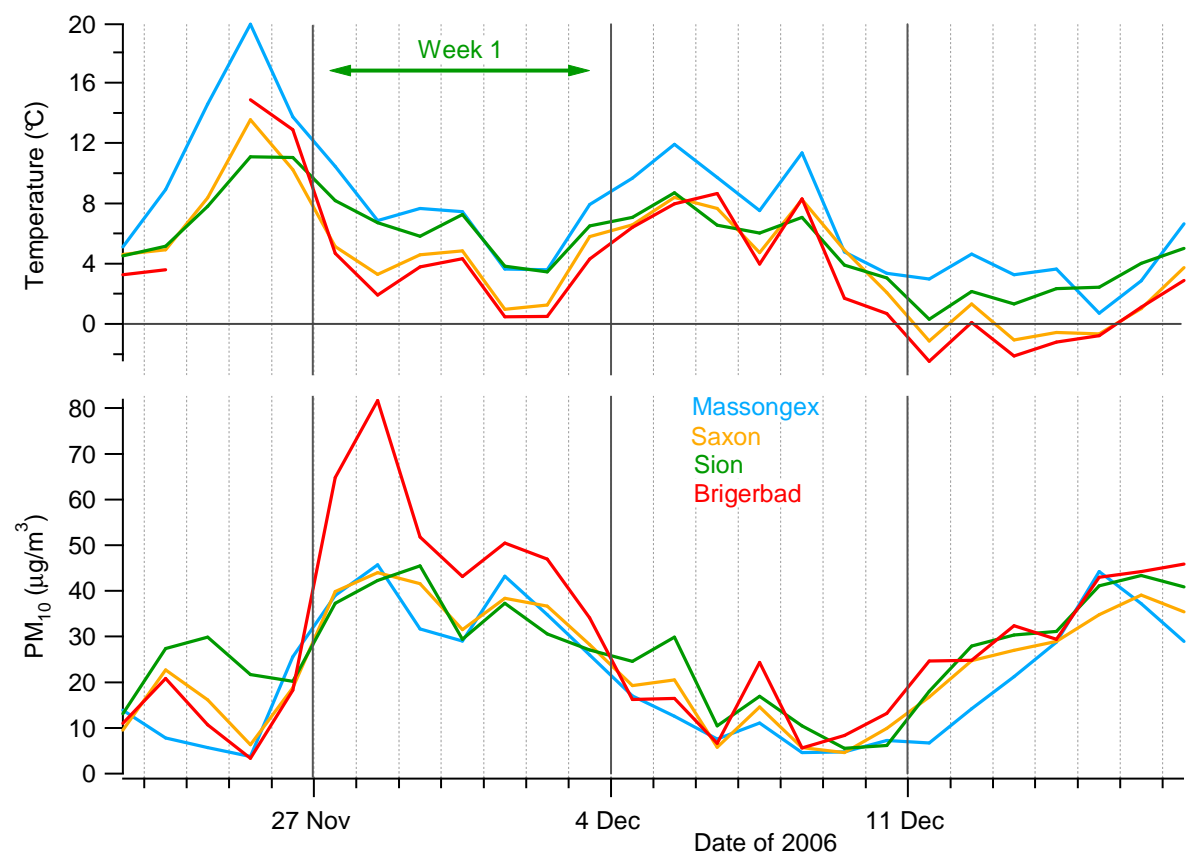

Title Page

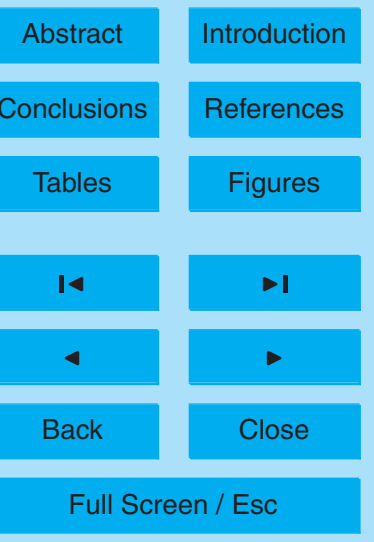

Fig. 2. $24 \mathrm{~h}$-averaged temperatures (top panel) and $\mathrm{PM}_{10}$ concentrations (bottom panel) at the four valley floor stations (Massongex, Saxon, Sion and Brigerbad) during the campaign.

Printer-friendly Version

Interactive Discussion 


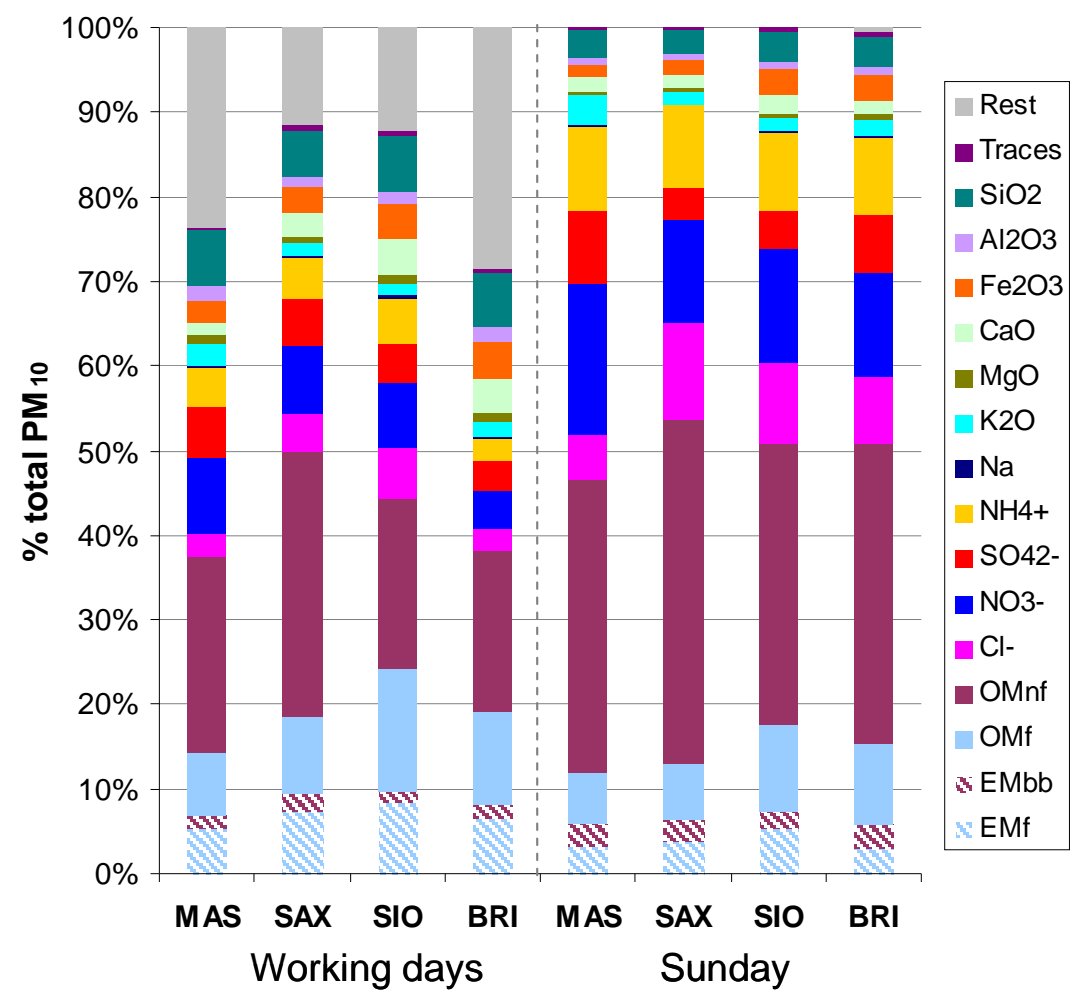

Fig. 3. $\mathrm{PM}_{10}$ compositions at the four stations, averaged for the working days 27 and 28 November and 1 December 2006 (left), and on Sunday 3 December 2006 (right). The metals likely to belong to mineral dust were considered as oxides. The following carbon-to-total mass ratios were considered: $(\mathrm{OM} / \mathrm{OC})=1.5$ and 1.7 for fossil and non-fossil organics, respectively, and $E M / E C=1.1$ for both fossil and non-fossil EC.

\section{ACPD}

10, 9391-9430, 2010

Composition and sources of

\section{particulate matter}

N. Perron et al.

Title Page

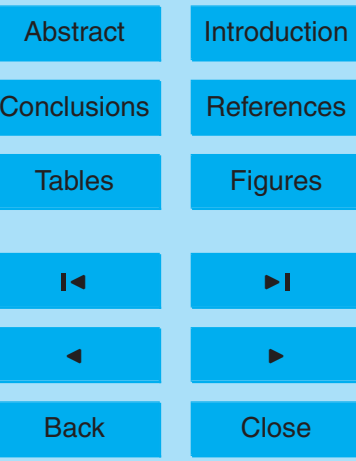

Full Screen / Esc

Printer-friendly Version

Interactive Discussion 


\section{ACPD}

10, 9391-9430, 2010
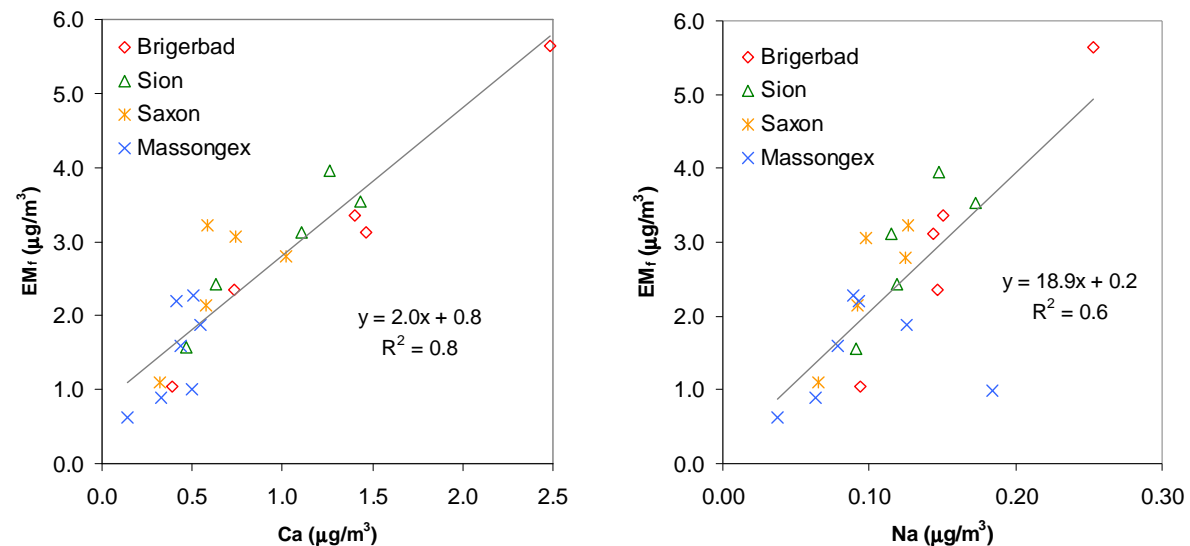

Composition and sources of particulate matter

N. Perron et al.

Title Page

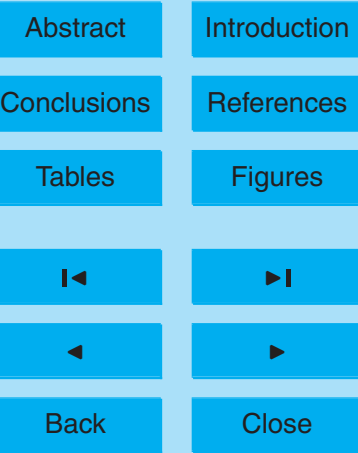

Full Screen / Esc

Printer-friendly Version

Interactive Discussion 


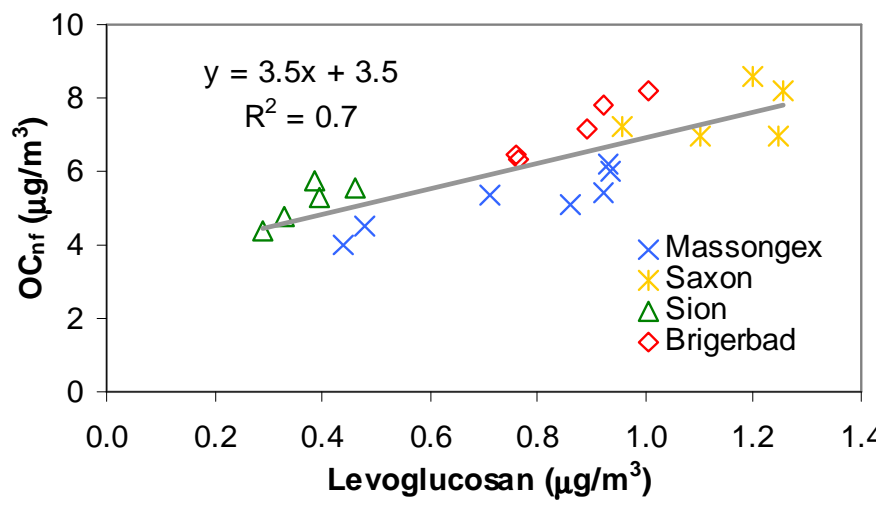

ACPD

$10,9391-9430,2010$

Composition and sources of particulate matter

N. Perron et al.

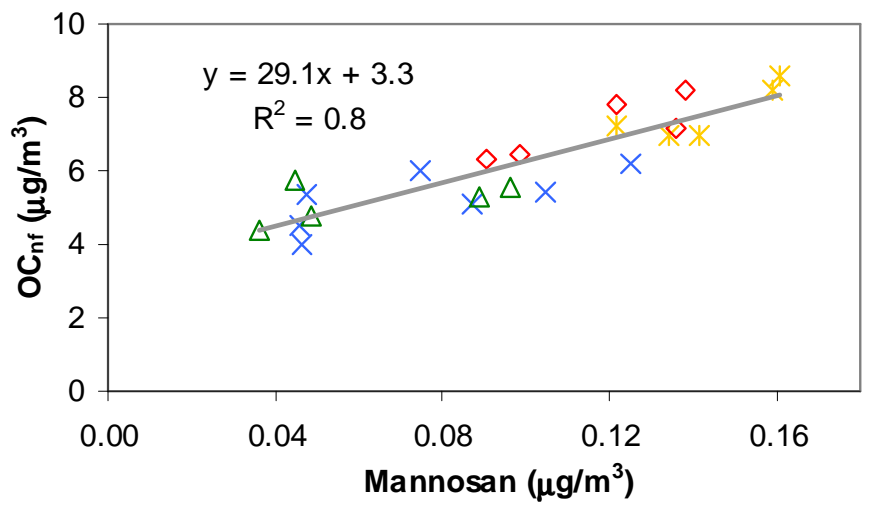

Title Page

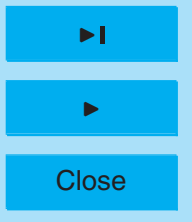

Fig. 5. Comparison of anhydrosugars and ${ }^{14} \mathrm{C}$-deduced non-fossil $\mathrm{OC}$ concentrations at the four stations: levoglucosan and $\mathrm{OC}_{\mathrm{nf}}$ (top), and mannosan and $\mathrm{OC}_{\mathrm{nf}}$ (bottom). 
Traffic-induced resuspension

- Traffic carbonaceous

Secondary inorganics

non-fossil carbonaceous (including wood burning)

Others

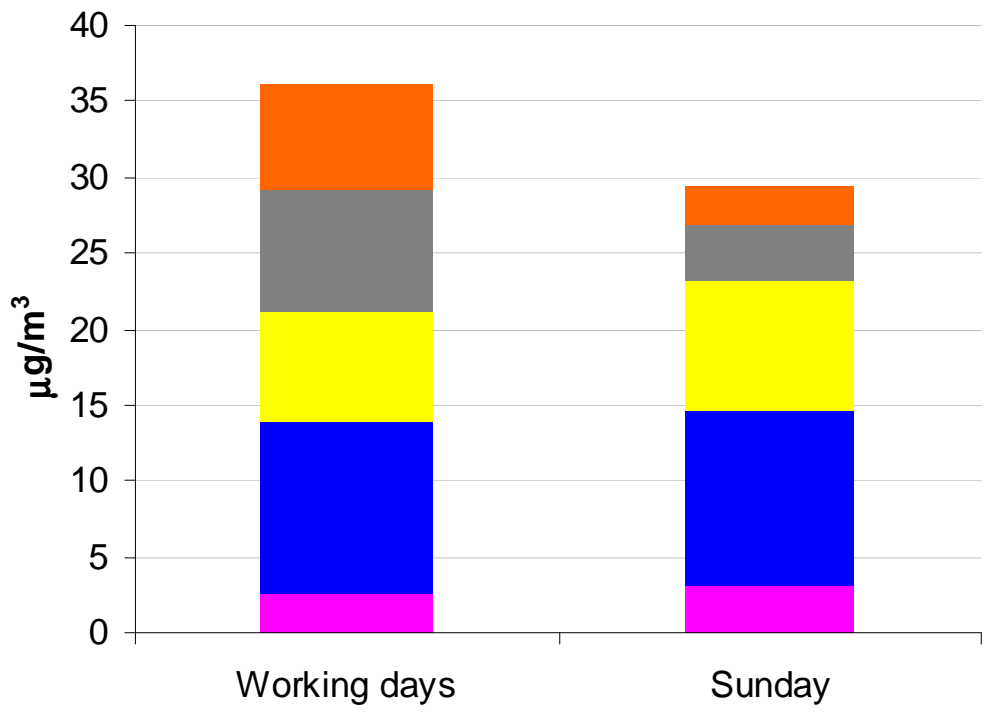

Fig. 6. $\mathrm{PM}_{10}$ source apportionment averaged for the four stations and for the working days 27 and 28 November and 1 December 2006 and the Sunday 3 December 2006. Traffic-induced resupension includes mineral dust as well as $\mathrm{Na}, \mathrm{Mn}, \mathrm{Cu}$ and $\mathrm{Zn}$; traffic carbonaceous: $\mathrm{EM}_{\mathrm{f}}$ and $\mathrm{OM}_{\mathrm{f}}$; secondary organics: nitrate, sulphate and ammonium; non-fossil carbonaceous: $\mathrm{EC}_{\mathrm{wb}}$ and $\mathrm{OM}_{\mathrm{nf}}$; and others: chloride, and trace elements others than $\mathrm{Mn}, \mathrm{Cu}$ and $\mathrm{Zn}$.

\section{ACPD}

10, 9391-9430, 2010

Composition and sources of particulate matter

N. Perron et al.

Title Page

Abstract

Introduction

Conclusions

References

Tables

Figures

14

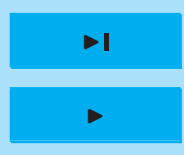

Back

Close

\section{Full Screen / Esc}

Printer-friendly Version

Interactive Discussion 


\section{ACPD}

10, 9391-9430, 2010

Composition and sources of

particulate matter

N. Perron et al.
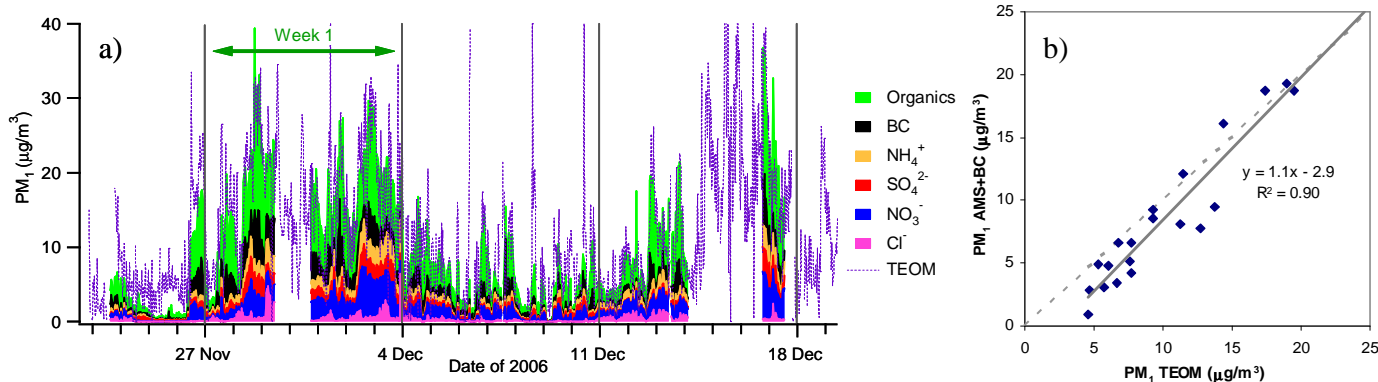

Fig. 7. (a) 30-min-time-resolved $\mathrm{PM}_{1}$ composition, deduced from AMS and Aethalometer measurements at Massongex. The collection efficiency used was $C E=0.5$. (b) Comparison between AMS+BC and TEOM $24 \mathrm{~h}$-averaged concentrations. The dashed line represents the 1:1 line.

Title Page

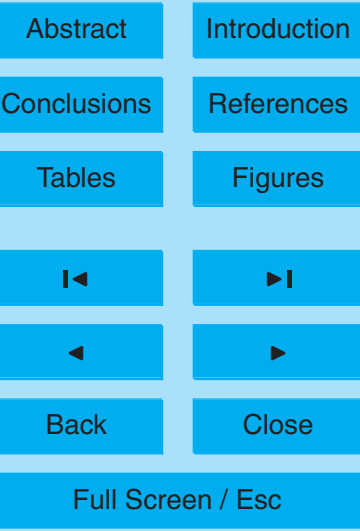

Printer-friendly Version

Interactive Discussion 


\section{ACPD}

10, 9391-9430, 2010

\section{Composition and sources of}

Working days

\begin{tabular}{|l|}
\hline$\square$ Organics \\
$\square \mathrm{BC}$ \\
$\square$ Chloride \\
$\square$ Ammonium \\
$\square$ Nitrate \\
$\square$ Sulphate \\
\hline
\end{tabular}

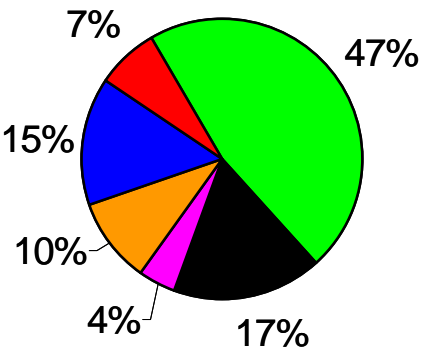

$11.5-19.5 \mu \mathrm{g} \cdot \mathrm{m}^{-3}$

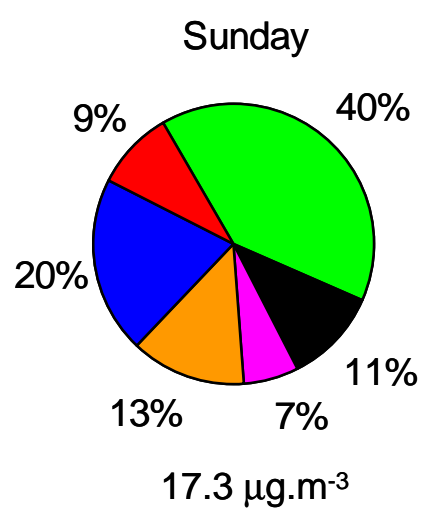

Fig. 8. Working days (left) and Sunday (right) $\mathrm{PM}_{1}$ composition at Massongex during the week 1 , deduced from AMS and Aethalometer measurements. The working days correspond to 27 and 28 November and 1 December 2006, whereas Sunday refers to the 3 December 2006.

\section{particulate matter}

N. Perron et al.

Title Page

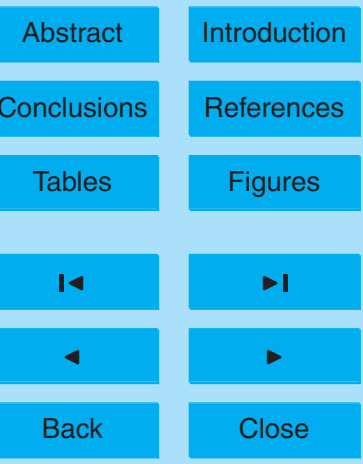

Full Screen / Esc

Printer-friendly Version

Interactive Discussion 


\section{ACPD}

$10,9391-9430,2010$
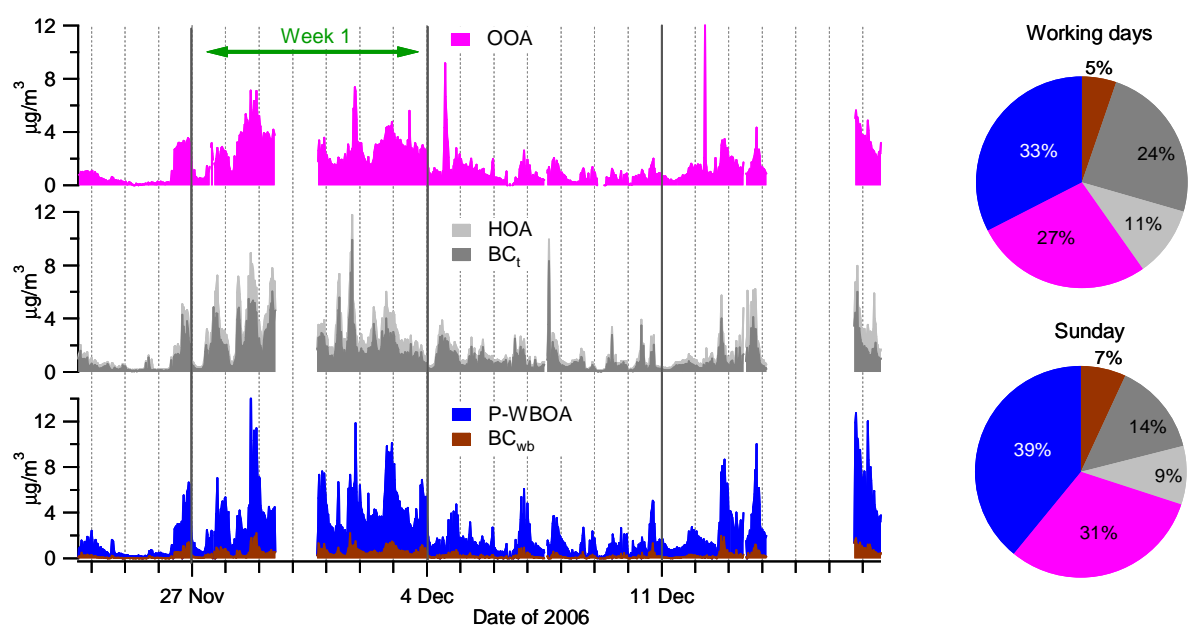

Fig. 9. Left: time series of the different contributors to the $P M_{1}$ carbonaceous aerosol (OOA, $\mathrm{HOA}, \mathrm{BC}_{\mathrm{t}}, \mathrm{P}-\mathrm{WBOA}$ and $\mathrm{BC}_{\mathrm{wb}}$ ) in Massongex during the whole campaign. Right: average composition of the $\mathrm{PM}_{1}$ carbonaceous aerosol for the following working days of week 1: 27 and 28 November and 1 December 2006, and for the Sunday 3 December 2006. OOA, HOA and $\mathrm{P}-\mathrm{WBOA}$ are deduced from ME-2-AMS, $\mathrm{BC}_{\mathrm{t}}$ and $\mathrm{BC}_{\mathrm{wb}}$ from the aethalometer model.

\section{Composition and sources of particulate matter}

N. Perron et al.

\section{Title Page}

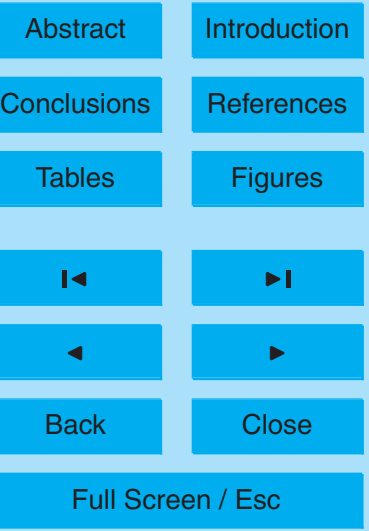

Printer-friendly Version

Interactive Discussion 


\section{ACPD}

10, 9391-9430, 2010
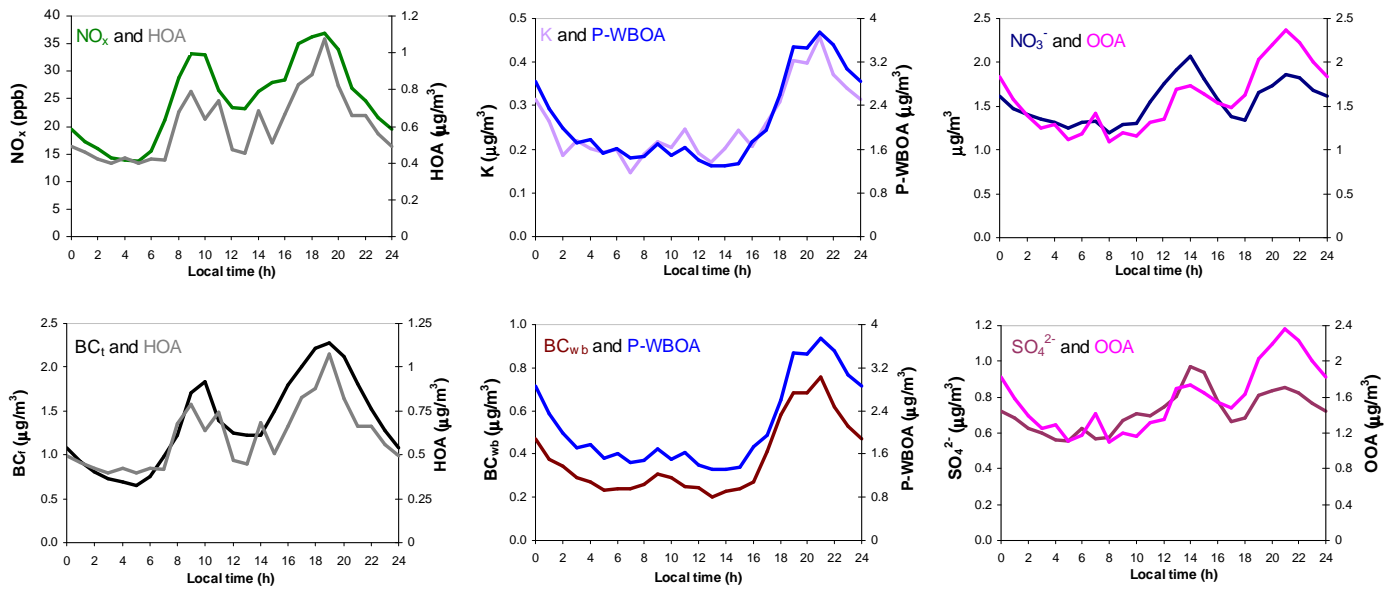

Fig. 10. Diurnal cycles in Massongex for $\mathrm{HOA}, \mathrm{P}-\mathrm{WBOA}, \mathrm{OOA}, \mathrm{NO}_{\mathrm{x}}, \mathrm{CO}, \mathrm{BC}_{\mathrm{t}}, \mathrm{BC}_{\mathrm{wb}}, \mathrm{K}, \mathrm{NO}^{3-}$, $\mathrm{NH}_{4}^{+}$and $\mathrm{SO}_{4}^{2-}$, averaged over the whole campaign.

\section{Composition and sources of} particulate matter

N. Perron et al.

Title Page

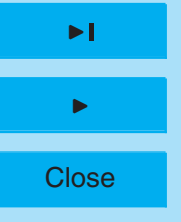




\section{ACPD}

10, 9391-9430, 2010

\section{Composition and sources of \\ particulate matter}
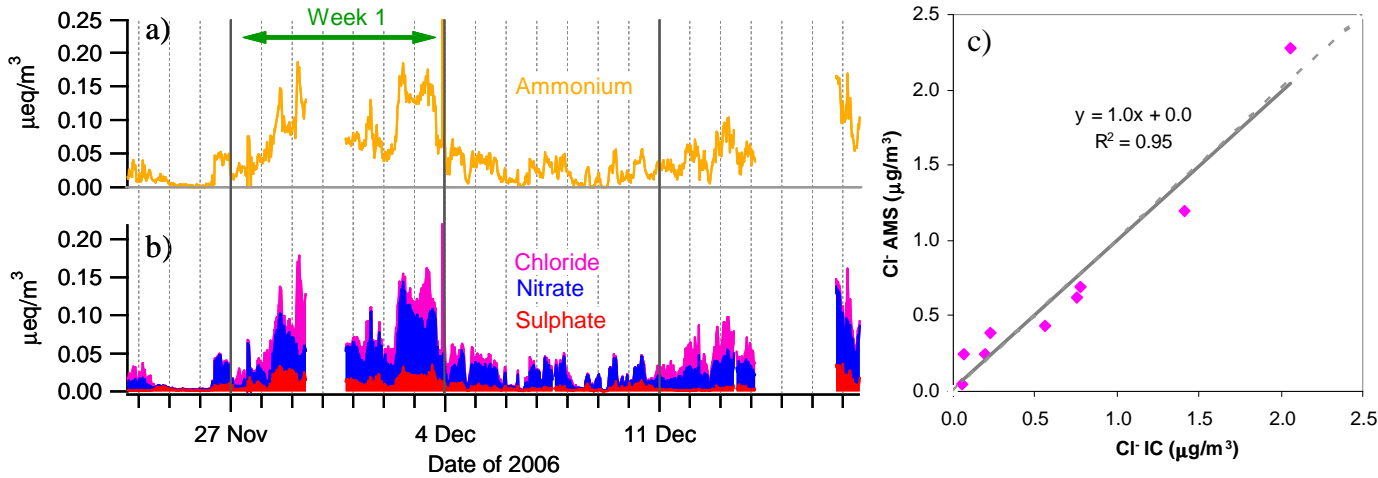

N. Perron et al.

Fig. 11. Time series of the ammonium (a) and summed chloride, nitrate and sulphate (b) AMS equivalent concentrations during the whole campaign, and comparison of chloride concentrations measured by AMS and IC (c).

Title Page

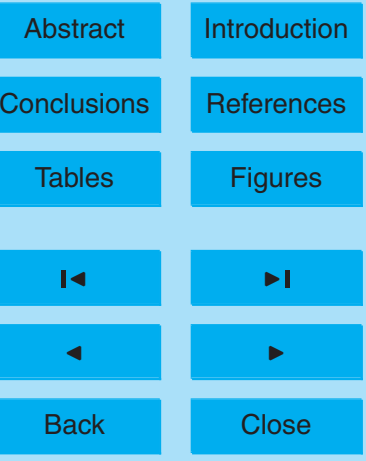

Full Screen / Esc

Printer-friendly Version

Interactive Discussion 